Drought Vulnerability Assessment to Inform Grazing Practices on Rangelands of Southeastern Colorado's Major Land Resource Area 69

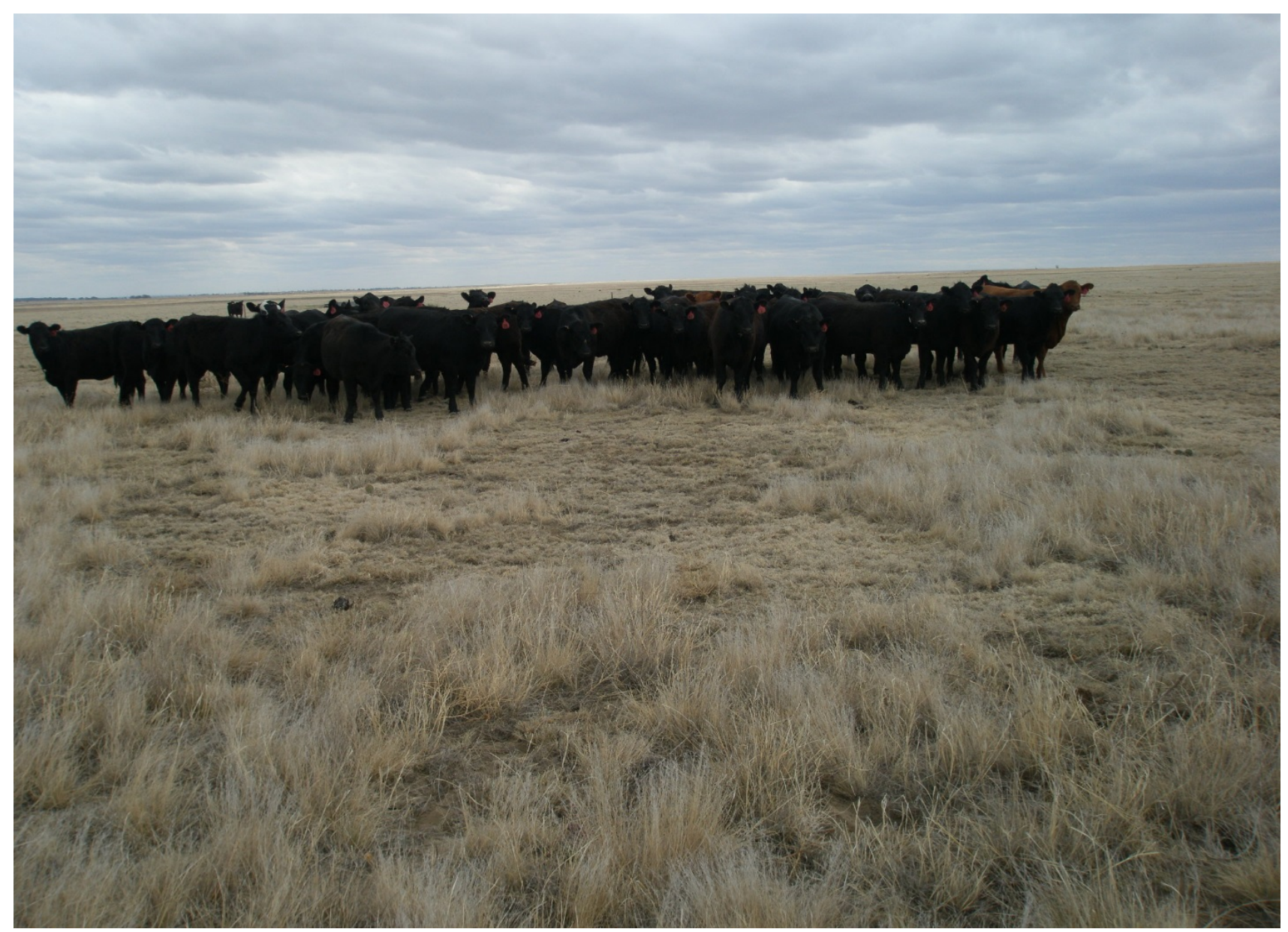

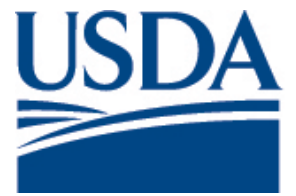

USDA

United States Department of Agriculture
United States Department of Agriculture Southwest Climate Hub

Natural Resources Conservation Service

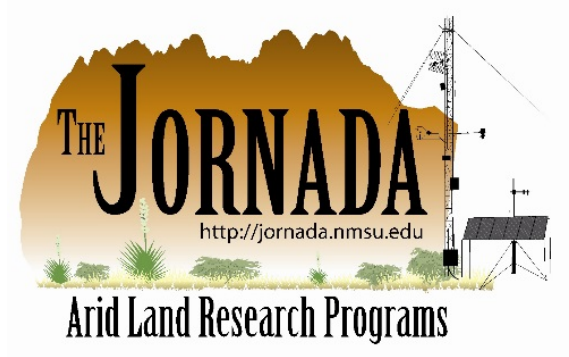




\title{
Drought Vulnerability Assessment to Inform Grazing Practices on Rangelands of Southeastern Colorado's Major Land Resource Area 69
}

\author{
Authors: \\ Amber Wyndham \\ Emile Elias \\ Joel R. Brown \\ Michael A. Wilson \\ Albert Rango
}

Amber Wyndham is the U.S. Department of Agriculture - Natural Resources Conservation Service Liaison to the USDA Southwest Climate Hub, Pueblo, CO

Emile Elias is the U.S. Department of Agriculture - Agriculture Research Service Southwest Climate Hub Deputy Director, Las Cruces, NM

Joel R. Brown is the U.S. Department of Agriculture - Natural Resources Conservation Service National Leader for Ecological Inventory, Las Cruces, NM

Michael A. Wilson, is the U.S. Department of Agriculture - Natural Resources Conservation Service National Leader for Climate Change, Lincoln, NE

Albert Rango, is the U.S. Department of Agriculture - Agriculture Research Service Southwest Climate Hub Director, Las Cruces, NM 


\section{Abstract}

Increased climate variability, including more frequent and intense drought, is projected for the southwestern region of the United States. Increased temperatures and reduced precipitation lower soil water availability resulting in decreased plant productivity and altering species composition which may affect forage quality and quantity. Reduced forage quality and increased heat stress attributable to warmer temperatures could lead to decreased livestock performance in this system, which is extensively used for livestock grazing. Mitigating the effects of increasing drought is critical to social and ecological stability in the region. Reduced stocking rates, change in livestock breeds and/or grazing practices are general recommendations that could be implemented to cope with increased climatic stress. Ecological Sites (ESs) and their associated state and transition models (STMs) are tools to help land managers implement and evaluate responses to disturbances. The projected change in climate will vary depending on geographic location. Vulnerability assessments and adaptation strategies are needed at the local level to inform local management decisions and help ameliorate the effects of climate change on rangelands. The USDA Southwest Climate Hub and Natural Resources Conservation Service (NRCS) worked together to produce this drought vulnerability assessment at the Major Land Resource Area (MLRA) level based on ESs/STMs that will help landowners and government agencies identify and develop adaptation options for drought on rangelands. The assessment illustrates how site-specific information can be used to help minimize the effects of drought on rangelands and support informed decision-making for selecting management adaptations within MLRA 69.

Keywords: drought, rangelands, grazing adaptation, MLRA 69, climate change, Colorado 


\section{Contents}

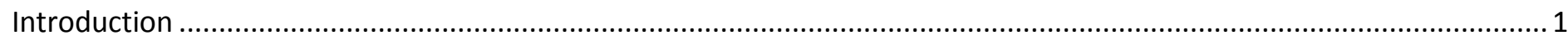

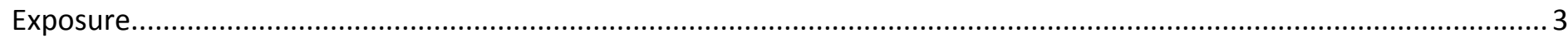

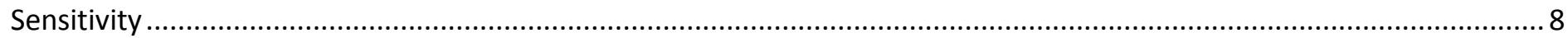

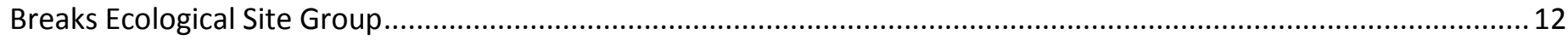

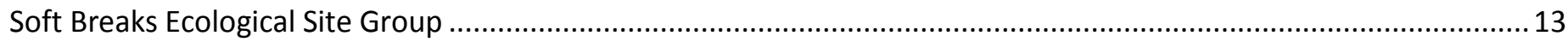

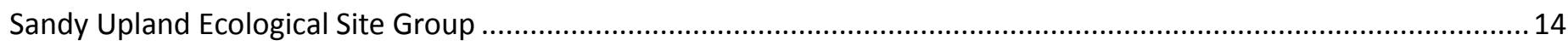

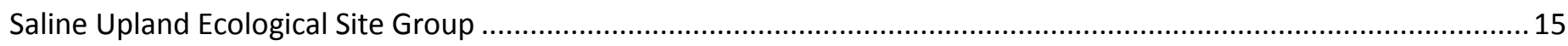

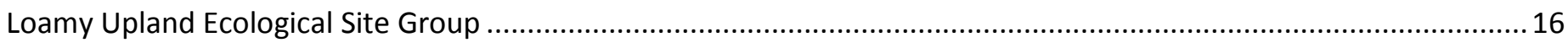

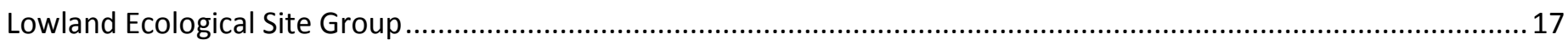

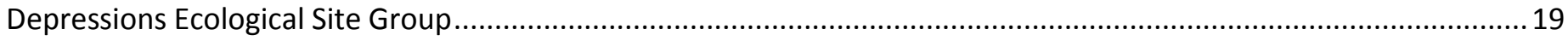

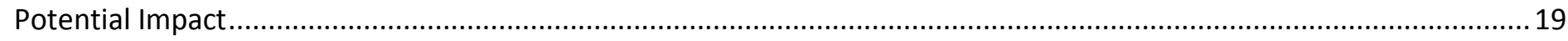

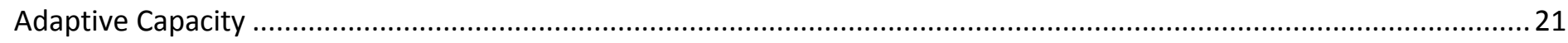

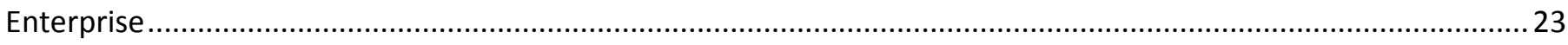

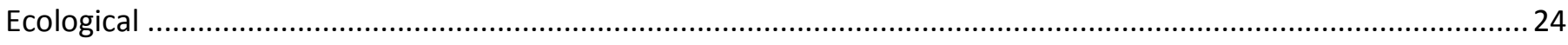

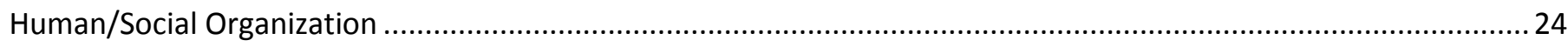

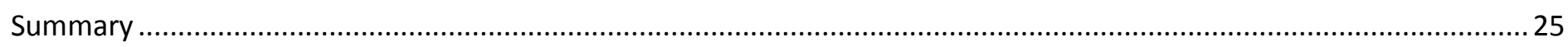

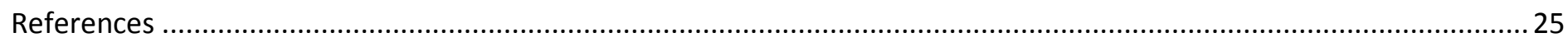

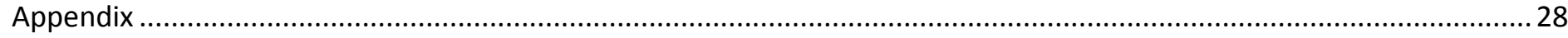

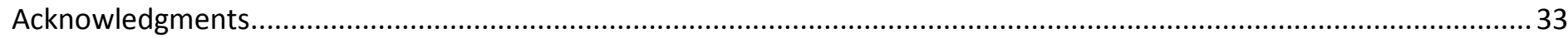




\section{Introduction}

Increasing atmospheric concentrations of greenhouse gases (GHG) has elevated global surface temperatures by $0.8^{\circ} \mathrm{C}$ (National Research Council, 2012) over the past 100 years and will likely exceed $1.5^{\circ} \mathrm{C}$ for the end of the $21^{\text {st }}$ century (IPCC, 2013). Elevated levels of greenhouse gases cause greater climate variability including more frequent and severe storms and drought in the southwestern Great Plains where rangeland is the major land use. Rangelands represent diverse arid and semiarid systems defined by low plant productivity, high precipitation variability and frequent drought (an extended period of relatively low precipitation). There are approximately 770 million acres of rangelands in the United States making up approximately $31 \%$ of the total land area and approximately $65 \%$ of the total land area in Colorado. Rangelands provide a multitude of goods and services including food, fiber, clean water, recreation opportunities, climate regulation, wildlife habitat, water and nutrient cycling (Havstad et al., 2007; Maczko et al., 2011). Rangelands goods and services are necessary to meet society's current and future needs and a changing climate may have an effect on these services. Elevated $\mathrm{CO}_{2}$ conditions may increase water use efficiency and plant production (Morgan et al., 2004) altering species composition and reducing forage quality (Milchunas et al., 2005; Morgan et al., 2004) and quantity in a system extensively used for livestock grazing. Productivity varies due to the high variability of soils, climate, and landforms across rangelands. Understanding the limitations of the land is necessary to conserve rangelands and the services they provide. The projected change in climate will vary depending on geographic location. Vulnerability assessments and adaptation strategies are needed at the local level to minimize the detrimental effects of climate change on rangelands (Briske et al., 2015; Joyce et al., 2013).

The term "vulnerability" can have different interpretations. The Intergovernmental Panel on Climate Change (IPCC) defines vulnerability as the degree to which a system is susceptible to, or unable to cope with, adverse effects of climate change and is function of exposure, sensitivity and adaptability (Figure 1) (McCarthy et al., 2001). Determining the potential impact of drought on rangelands requires developing realistic estimates of exposure and sensitivity to prepare for a drought and adaptive capacity to understand ways to mitigate the effects of drought (Brown et al., 2016). This assessment will focus on contextual vulnerability using a systematic approach to assess the vulnerability of ecological sites to drought and adaptive measures to mitigate drought affects. Contextual vulnerability incorporates the socioecological approach that includes the institutional, biophysical, socio-economic and technological processes (Joyce et al., 2013; O'Brien et al., 2007). Vulnerability is influenced by the changing biophysical conditions and social, economic, political, institutional and technological structures and process (O'Brien et al., 2007)

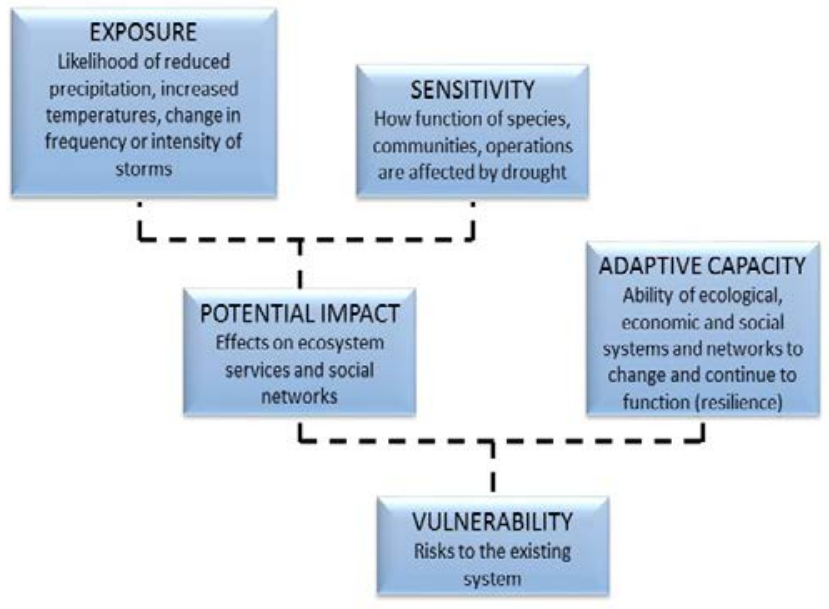

Figure 1. A vulnerability assessment framework for rangeland drought (Joyce et al., 2013). 
Ecological site (ES) descriptions developed by the USDA provide land owners with recommended management strategies based on site potential and can be used to help reduce the effects of climate variability at the local level. Ecological site concepts are uniquely developed within individual Major Land Resource Areas (MLRA), which is a component of the soil Land Resource Hierarchy (LRH). The LRH was developed by the USDA-NRCS to identify geographical areas at different levels of resolution that have similar capabilities and potentials for management (Bailey, 2014). The LRH divides landscapes into resource areas so that management and conservation plans can be applied. The current LRH is based on soil resources and does not include an ES component which are based on both vegetation and soil (Figure 2). Salley et al. (2016) proposed incorporating ecological site concepts into the hierarchy to aid in the development of ESs and to provide spatial scaling links between ecological scales of the LRH. Furthermore, including ecological sites into the LRH will aid in evaluating biotic and abiotic influences as landscapes are organized at the local level (Figure 2) (Salley et al., 2016).This assessment will apply ES to evaluate how site-specific information can reduce the effects of drought on rangelands and improve decision making for selecting management adaptations within Major Land Resource Area (MLRA) 69 in southeast Colorado. MLRAs are geographically associated landscape classification components based on similar geology, landscapes/landforms, climate, soils, vegetation and land use. MLRAs were developed by the USDANatural Resources Conservation Service (NRCS) to assist with conservation planning.

Soil-LAND RESOURCE HIERARCHY

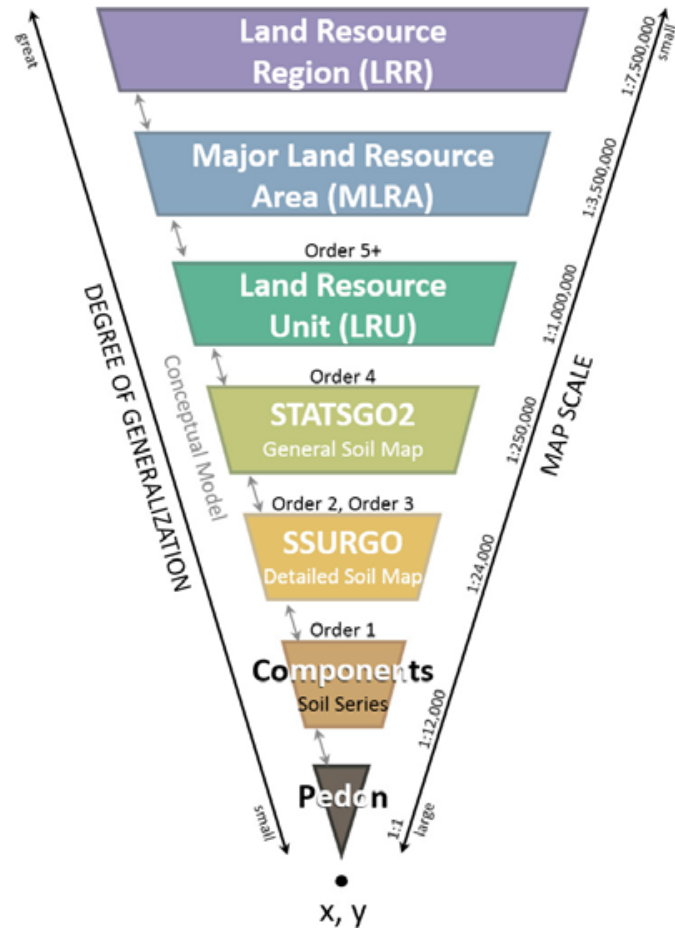

\section{Ecological-LAND RESOURCE HIERARCHY}

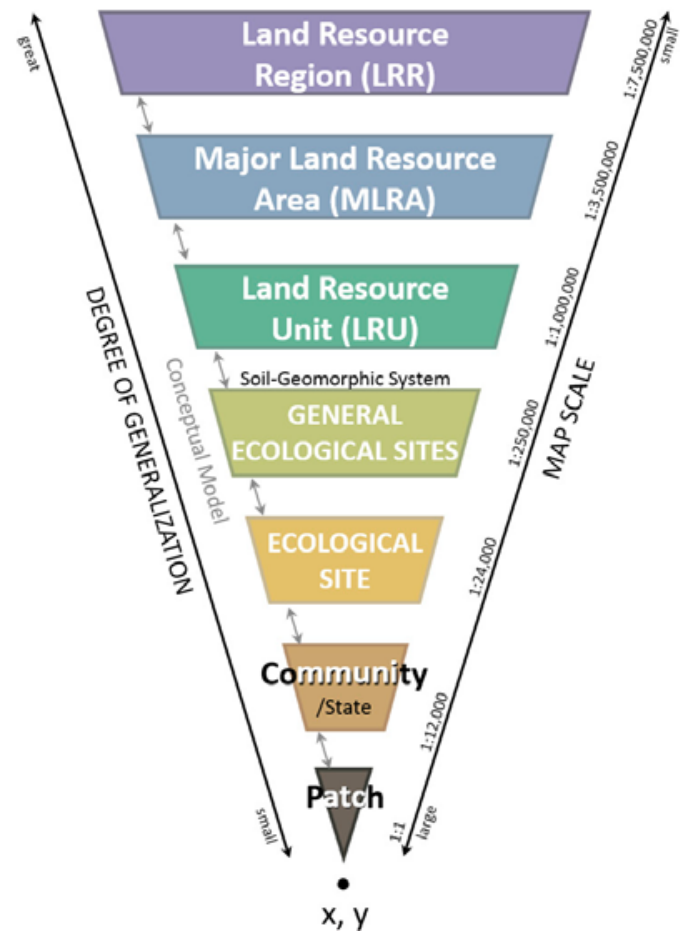

Figure 2. NRCS Land Resource Hierarchy of soil and ecological resources (Salley et al., 2016)

MLRA 69 is located in the Upper Arkansas Valley Rolling Plains of southeastern Colorado and covers approximately 7.6 million acres across 13 counties (Figure 3). This MLRA is an elevated plain of sediments deposited by rivers that drain from the young and actively eroding Rocky Mountains. Its topography includes undulating to rolling plains, canyonlands, and/or dissected basalt flows. Landforms include interfluves, fa.ns, fan remnants, plains, hills, ridges, terraces, floodplains, and scarps. The geology of MLRA 69 includes alluvium, eolian deposits, loess, limestone, sandstone, and shale. The soil temperature regime is mesic and soil moisture regime is ustic aridic or aridic ustic. Elevations range from 1097 to 1890 meters above sea level (MASL) and annual precipitation ranges from 254 to 406 millimeters (mm) which occurs mostly during the growing season from mid-April to late September. The average length of the freeze-free period $\left(-2.2^{\circ} \mathrm{C}\right)$ is 162 days. The average date of the first freeze $\left(\leq-2.2^{\circ} \mathrm{C}\right)$ in the fall is October 16 and average last freeze in the 
spring is April 21. Mean annual air temperature is $8.8-12.2^{\circ} \mathrm{C}$ and summer temperatures typically exceed $37.7^{\circ} \mathrm{C}$. Winter temperatures are occasionally sub-zero, and annual snowfall varies from 51-102 centimeters. Approximately $80 \%$ of the MLRA consists of grazing lands dominated by shortgrass prairies. Depending on the site, vegetation includes oneseed juniper (Juniperus monosperma), pinyon-pine (Pinus edulis), fourwing saltbush (Atriplex canescens), bigelow sage (Artemisia bigelovii), winterfat (Krascheninnikovia Guldenstaedt) and tree cholla (Cylindropuntia imbricata). Grasses are predominantly warm-season and include blue grama (Bouteloua gracilis), galleta (Pleuraphis Torr), vine mesquite (Panicum obtusum), alkali sacaton (Sporobolus airoides), and buffalo grass (Bouteloua dactyloides). Sideoats grama (Bouteloua curtipendula), little bluestem (Schizachyrium scoparium) and silver bluestem (Bothriochloa saccharoides) occur in lesser amounts. Cool-season grasses are western wheatgrass (Pascopyrum smithii) and New Mexico feathergrass (Hespertostipa neomexicana Barkworth). Most rangelands are grazed by cattle and depending on soil properties, growing conditions and previous management the stocking rate recommendation ranges from 1.83 acres/animal unit months (AC/AUM) to $24.33 \mathrm{AC} / \mathrm{AUM}$. The majority of rangeland in MLRA 69 is relatively well managed according to NRCS and Colorado State University (CSU) Extension recommendations where $67-100 \%$ of the vegetation is a mixture of desirable plants such as grasses, legumes, forbs and shrubs. Flood plains and terraces are dominated by irrigated cropland along the Arkansas River and tributaries. Major crops include alfalfa, various chilies, melons, onions, and soybeans. Dominant soil orders include Entisols, Aridisols, Alfisols, and Mollisols. MLRA 69 consists of 19 ES's that have been combined for this report into 7 groups based on similar management and disturbance responses. Climate risk vulnerability will be developed based on site characteristics within the 7 ES groups which will define grazing management recommendations and/or adaptation strategies.

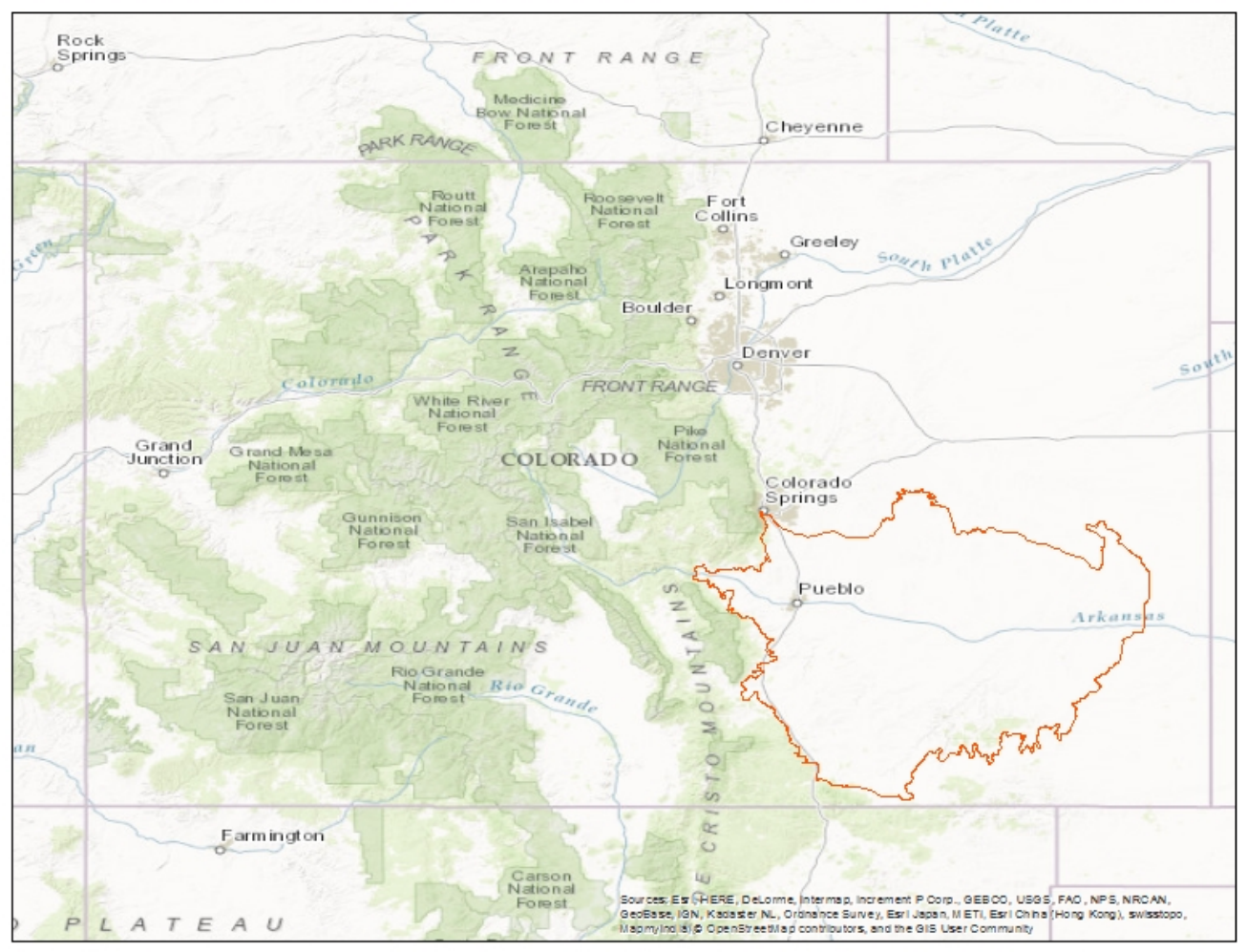

Figure 3: Major Land Resource Area 69 located along the southwestern Great Plains.

\section{Exposure}

Colorado's topography varies and includes the mesas and canyons in the west, the centrally located Rocky Mountains and the Great Plains to the east. This diverse range of topography leads to a highly variable climate in a state where elevations range from 1,010 to 4,402 MASL. Average annual temperatures have increased approximately $1.1^{\circ} \mathrm{C}$ since the early $20^{\text {th }}$ century in Colorado and climate models project that the average annual temperature will increase 3.3 to $7.7^{\circ} \mathrm{C}$ 
by the end of the $21^{\text {st }}$ century if GHGs continue to increase (Figure 4) (Frankson and Kunkel, 2017). Climate models predict that in the next 20 years the mean annual temperature will increase 1.1 to $1.6^{\circ} \mathrm{C}$ across Colorado and approximately $1.1^{\circ} \mathrm{C}$ for MLRA 69 (Abatzoglou, 2017).

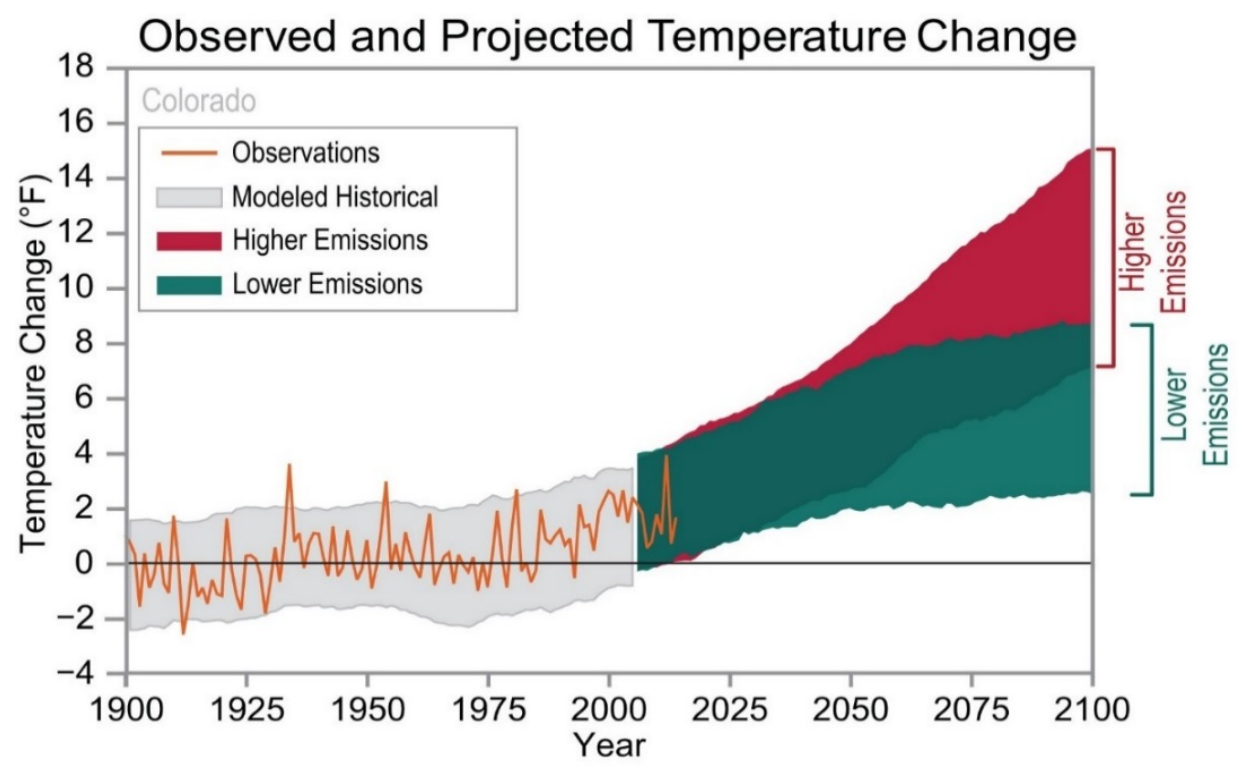

Figure 4: Observed and projected changes in near surface air temperature for Colorado

The complexity and interactions of the atmospheric processes make it difficult for global climate models to predict changes in future precipitation patterns (Knapp et al., 2008). The topography of the state influences the distribution of precipitation across Colorado (Figure 5 ) and due to the high variability in precipitation across the state no consistent long-term trends in annual precipitation have been observed. Current annual precipitation ranges from $178 \mathrm{~mm}$ in the San Luis Valley to more than 1,524 $\mathrm{mm}$ in the higher Mountain regions.

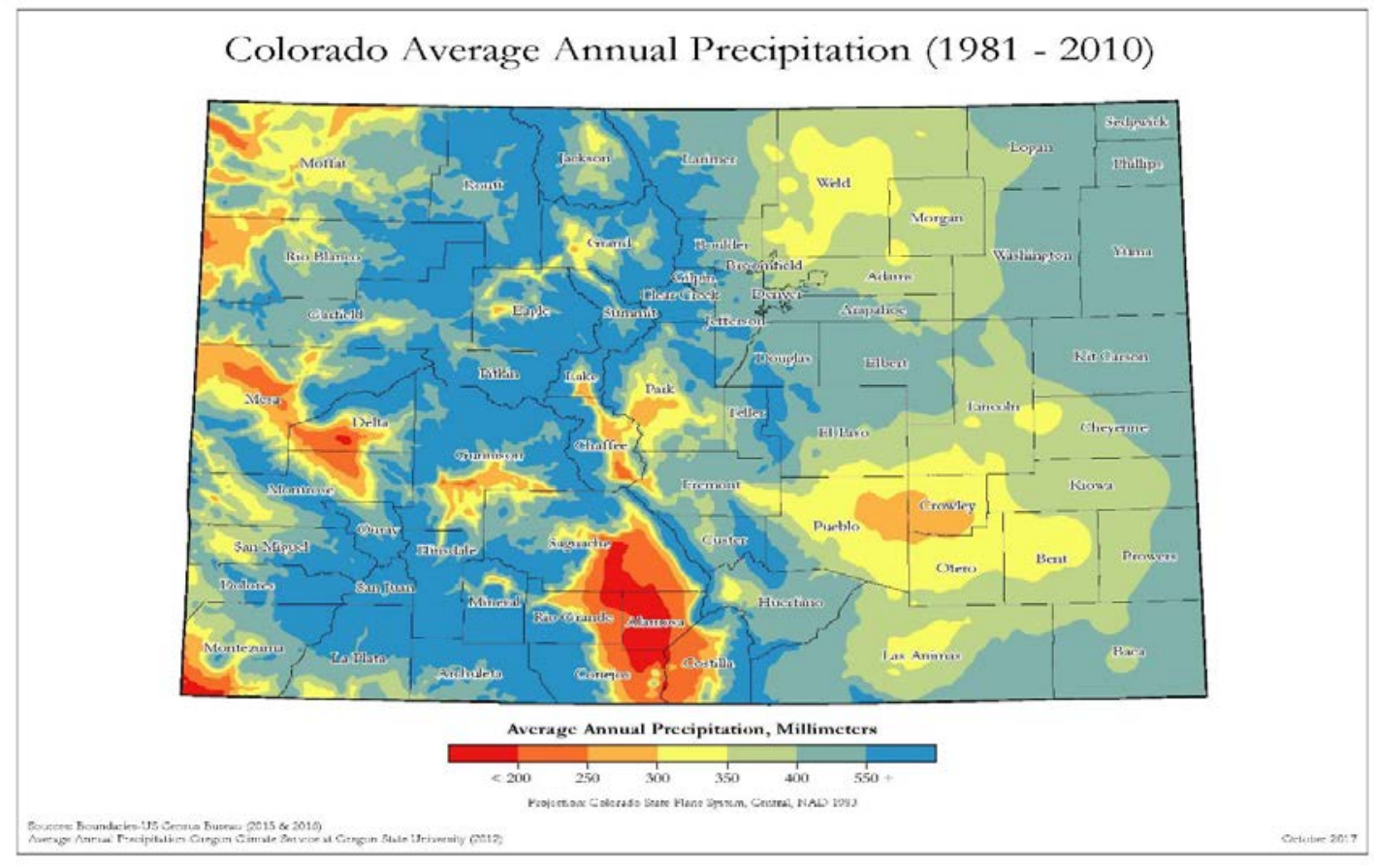

Figure 5. Colorado Average Annual Precipitation from 1981-2010. 
Colorado mountains are the headwaters of 4 major rivers, therefore changes in precipitation can affect the water supply of other States. Up to $80 \%$ of Colorado's surface water originates from snowpack that melts between April and July providing water for most of urban and rural Colorado (Henz et al., 2004). Spring precipitation amounts have been below average since 2000, but recent average spring temperatures have been the highest on record for the state (Figure 6).
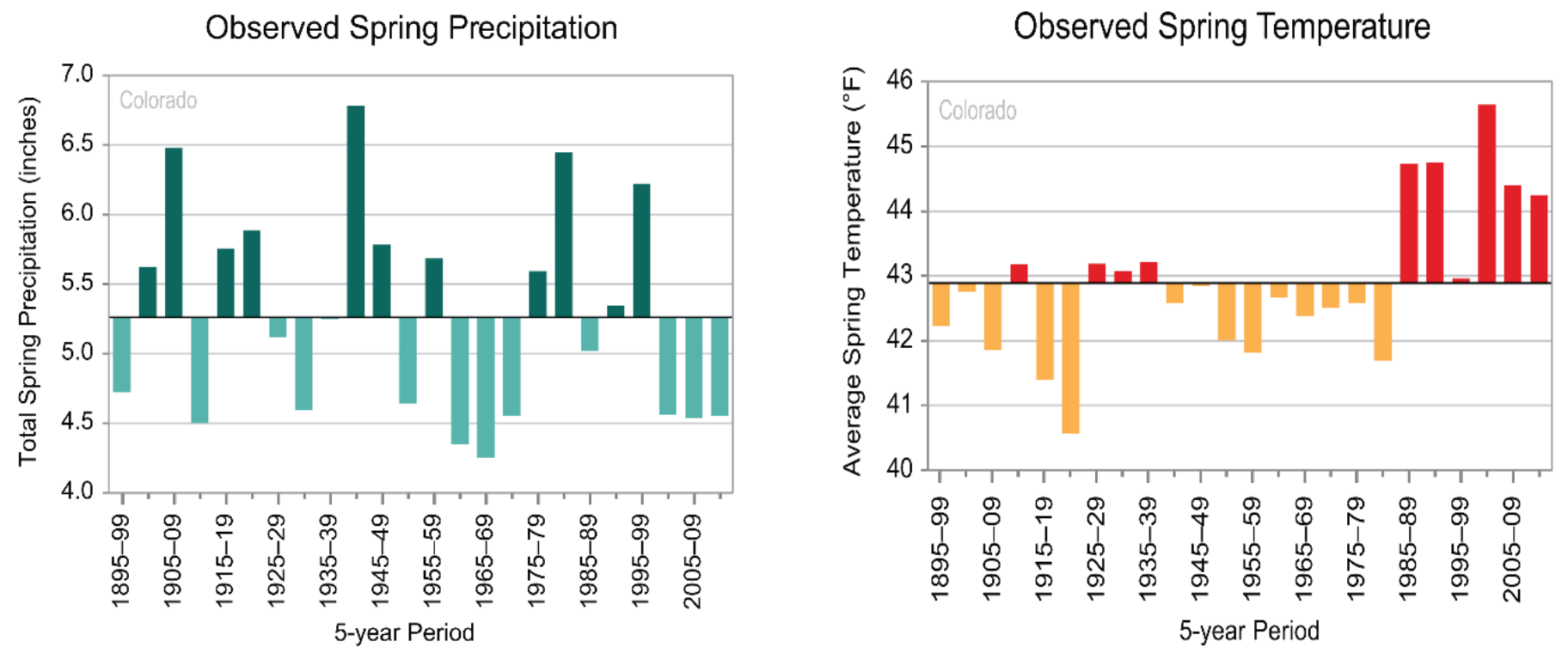

Figure 6: Observed Spring Precipitation and Temperature for Colorado (Frankson and Kunkel, 2017).

The number and intensity of recent precipitation events within the state remains consistent with historic observations, however, climate models predict that more intense precipitation events are likely to increase across Colorado as warming continues (Frankson and Kunkel, 2017). Semi-arid environments typically have low moisture events and high evaporation demand, however, increased intensity with longer periods between storms may result in less soil water being lost to evaporation, reducing the plant and soil processes stress levels as the soil water levels are recharged (Knapp et al., 2008). Seasonal precipitation is projected to increase in the winter and decreased in the summer. Less snow and more rain is expected during the winter months as temperatures rise, thus reducing overall water availability (Frankson and Kunkel, 2017).

Annual and spring precipitation amounts were below average for 2000-2004 and 2010-2014 leading to severe droughts in 2002, 2012 and 2013 and an elevated wildfire season. Drought is a frequent occurrence in Colorado that typically lasts 6 months or less. Throughout time short duration ( $<3$ months) droughts have previously affected $80 \%$ of the state where as longer duration (2-4 years) droughts have impacted as much as $70 \%$ of the state (Henz et al., 2004). The intensity of droughts is predicted to increase, thus affecting interrelated ecological processes, such as fire frequency and insect outbreak. Insect outbreaks (Ferrell, 1996) may influence fire frequency due to greater amounts of dead vegetation and woody fuels.

The National Drought Mitigation Center (NDMC) defines drought as deficiency of precipitation over an extended period of time and its impacts vary from region to region. There are four types of drought described by Henz et al. (2004).

- Meteorological drought - expression of precipitations departure from normal over some period of time and is the first indicator of drought.

- Agricultural drought - occurs when there is a lack of soil moisture availability that affects crop and/or rangeland production.

- Hydrological drought - refers to deficiencies in surface and subsurface water supplies and is measured as streamflow and as lake, reservoir, and groundwater levels. 
- Socioeconomic drought - occurs when water shortages start to affect people and is associated with supply and demand.

Key variables in assessing drought are precipitation, snowpack and streamflow and determining the impacts of drought can be described by evaluating the following drought characteristics (Henz et al., 2004).

- Magnitude (size of water deficits compared to historic average)

- Duration (length of time the drought persists)

- Severity (combination of the magnitude and duration) (Appendix - Table A1)

- Spatial extent (what area is impacted by the drought)

There are several types of indicators or indices that are used to help track droughts and provide information before, during, and after droughts to aid with decision making and formulation of drought management plans as a means of reducing potential impacts (Appendix - Table A2).

Two types of drought defining magnitude and pattern, are expected to increase over the next century with each having different effects on ecosystem properties and processes. Press droughts occur when there is long-term reduction in precipitation (e.g. 10\% decrease in MAP) and soil moisture, with increased temperatures and potential evapotranspiration. Pulse droughts are short in duration, but more extreme in magnitude (e.g. $<5^{\text {th }}$ percentile annual rainfall) (Hoover and Rogers, 2016; IPCC, 2013) Pulse droughts (e.g. Great Plains 2012 drought) affect C storage and cycling as gross primary production has greater sensitivity to drought than ecosystem respiration. Rangelands are more resistant to press droughts than pulse droughts as more $\mathrm{C}$ is lost during extreme pulse droughts (Hoover and Rogers, 2016).

Precipitation events in the Southwestern Great Plains are typically short where much of the moisture is evaporated and soils maintain a low soil water content. Most of the moisture received in the MLRA 69 is received in spring and summer where the average precipitation ranges from 102-127 mm in May through September (Figure 7). Thunderstorms are common which can lead to flash flooding and hail storms. Climate models predict a slight increase in mean annual precipitation for MLRA 69, however, increasing mean annual temperatures and potential evapotranspiration will lead to drier conditions for the area (Table 1). Warmer temperatures result in more days above freezing leading to a longer growing season (Abatzoglou, 2017) and greater abundance of warm season grasses (Epstein et al., 2002). The structure and function of the shortgrass steppe ecosystem in MLRA 69 is dependent on precipitation, grazing and fire (Pielke et al., 2005; Rondeau et al., 2013), therefore understanding the response of vegetation to the changing climate will aid in drought management.

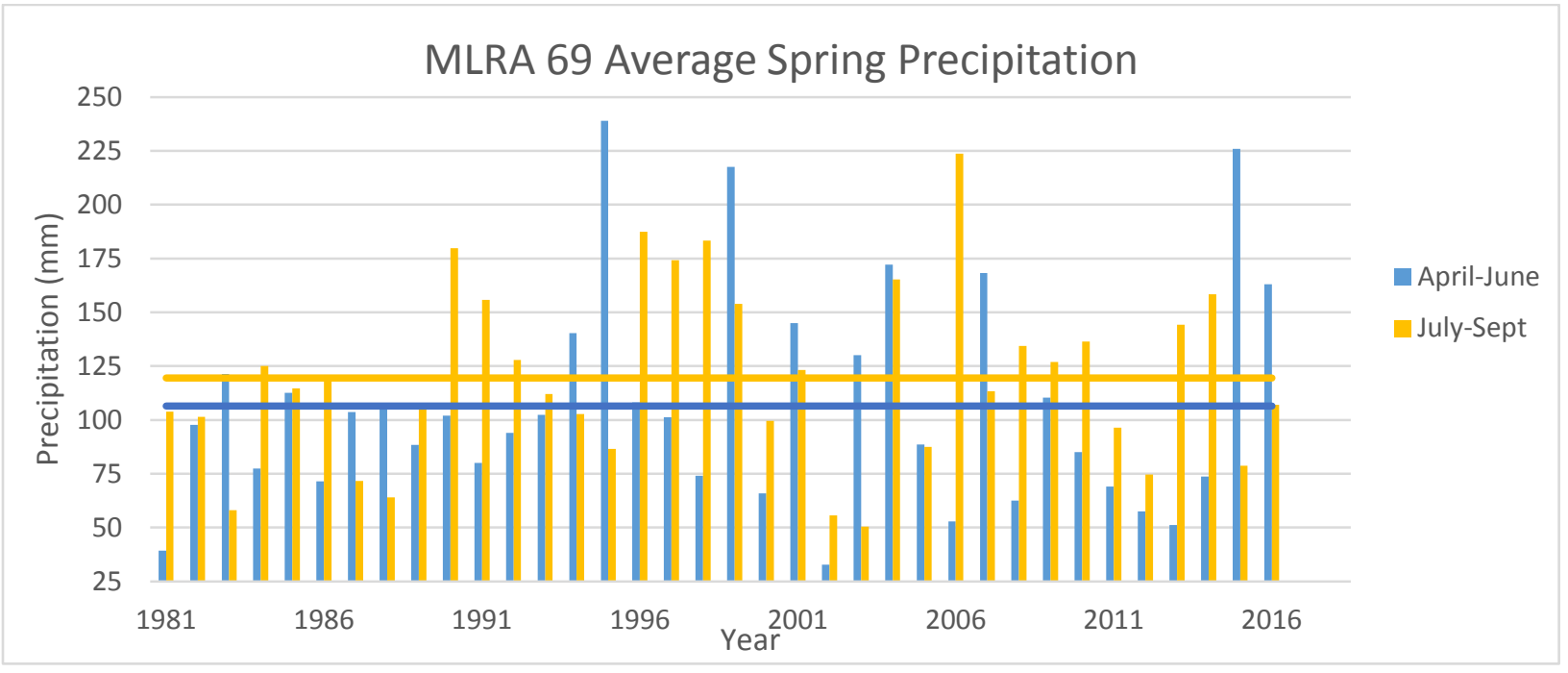

Figure 7. Average Spring Precipitation for MLRA 69 
Table 1. MLRA 69 Historic and Future Climate Projections

\begin{tabular}{|c|c|c|c|c|c|c|c|}
\hline $\begin{array}{c}\text { Low/High } \\
\text { Emissions and Year }\end{array}$ & $\begin{array}{l}\text { Mean } \\
\text { Annual } \\
\text { Precip } \\
(\mathrm{mm}) \\
\end{array}$ & $\begin{array}{c}\text { Mean } \\
\text { Annual PET } \\
(\mathrm{mm})\end{array}$ & $\begin{array}{c}\text { Mean } \\
\text { Annual } \\
\text { Summer } \\
\text { Min Temp } \\
\text { (C) }\end{array}$ & $\begin{array}{c}\text { Mean } \\
\text { Annual } \\
\text { Summer } \\
\text { Max Temp } \\
\text { (C) }\end{array}$ & $\begin{array}{l}\text { Mean Annual } \\
\text { Winter } \\
\text { Min Temp } \\
\text { (C) }\end{array}$ & $\begin{array}{c}\text { Mean } \\
\text { Annual } \\
\text { Winter } \\
\text { Max Temp } \\
\text { (C) }\end{array}$ & $\begin{array}{c}\text { Mean } \\
\text { Annual } \\
\text { Freeze } \\
\text { Free } \\
\text { Days } \\
\end{array}$ \\
\hline $1981-2010$ & 299.7 & 1290.3 & 17.2 & 28.2 & -11.3 & 9.2 & 162 \\
\hline RCP4.5 2010-2039 & 340.36 & 1361.4 & 15.5 & 33.5 & -7.1 & 10.2 & 223.4 \\
\hline RCP8.5 2010-2039 & 337.8 & 1369.1 & 15.6 & 33.6 & -6.8 & 10.4 & 224.4 \\
\hline RCP4.5 2040-2069 & 337.8 & 1412.2 & 16.6 & 34.6 & -6.0 & 11.2 & 233.1 \\
\hline RCP8.5 2040-2069 & 335.3 & 1457.9 & 17.5 & 35.6 & -5.2 & 12.0 & 242 \\
\hline
\end{tabular}

*Western Regional Climate Center and Northwest Knowledge Network

Southeast Colorado was heavily affected by extended drought conditions in the Dust Bowl period of the 1930s, with recurrent drought cycles in 1950s, 1970s, 1980s, 2002, and 2011-2012 (Figure 8). The extreme drought of 2002 was considered to be the worst single-year drought in over 100 years (Pielke et al., 2005) that included the Hayman fire, the largest documented forest fire in Colorado and the severe drought in 2014 showed present day dust storms (Figure 9) similar to those that occurred during the Dust Bowl. Paleoclimatology data indicates that some droughts prior to 1600 were longer in duration and covered a larger area than the more recent droughts of the twentieth century (Woodhouse and Overpeck, 1998). However, increased drought severity and duration today or in the future would have greater impacts now due to the expanding metropolitan area and large-scale crop and livestock production.

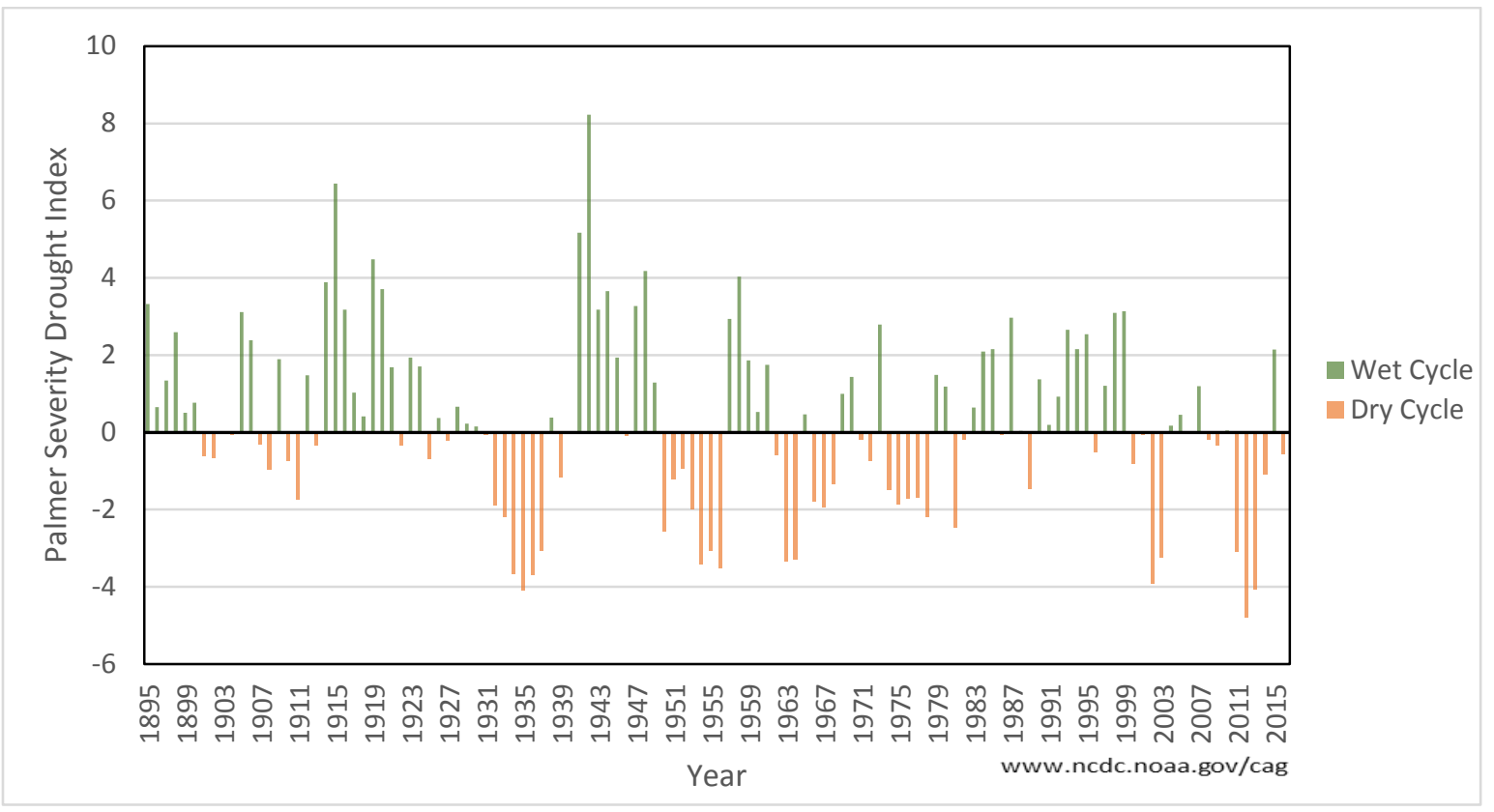

Figure 8. Southeast Colorado Palmer Severity Drought Index 


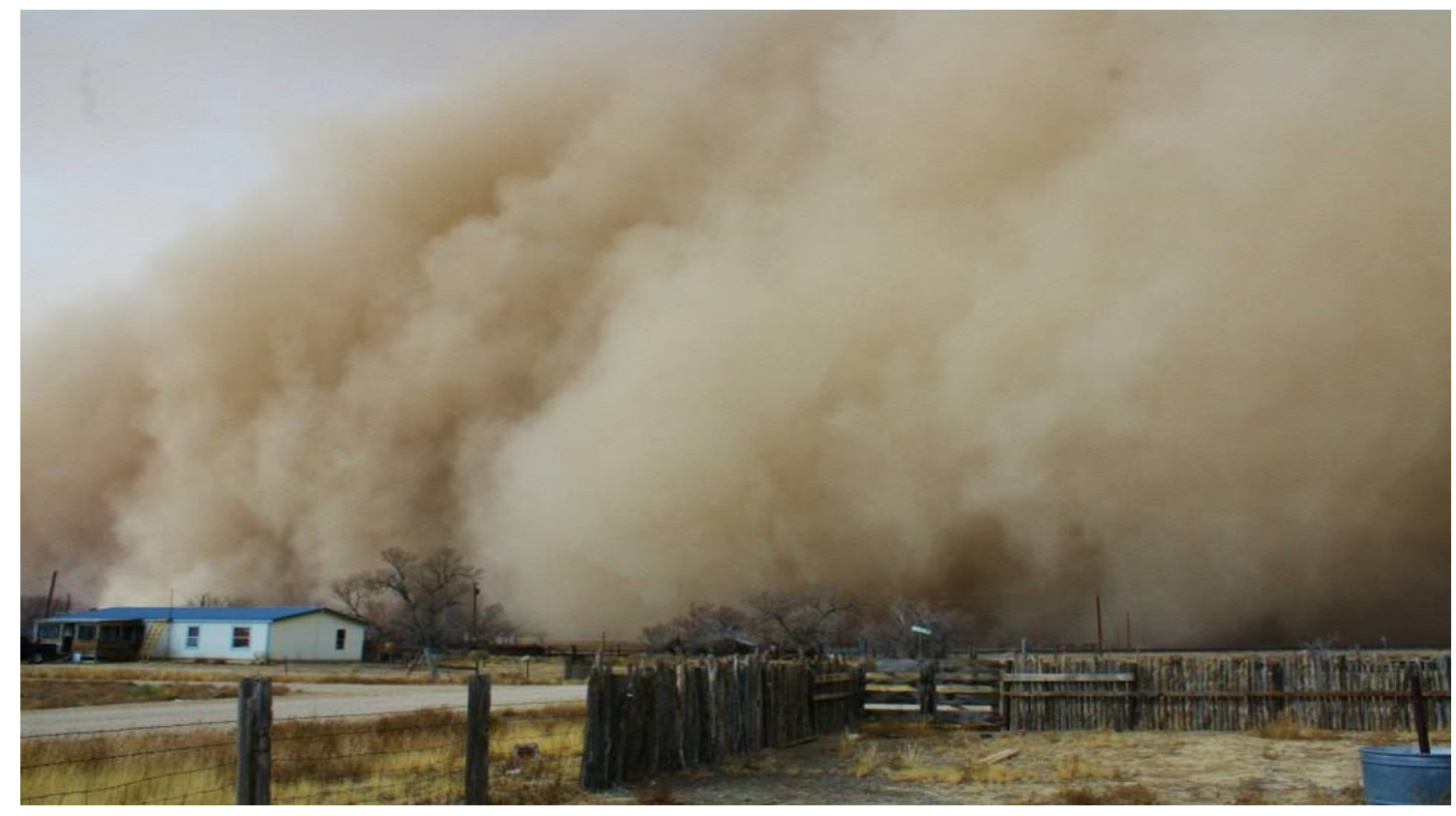

Figure 9. Dust storm during the 2014 drought in Otero County, Colorado located within MLRA 69.

Climate change is expected to have diverse consequences on US rangelands (Polley et al., 2013) as weather patterns will influence grazing practices and the livelihoods of millions of people (Briske et al., 2015). Rising temperatures and increased drought severity will lead to decreased livestock performance and production due to heat stress, reduced forage quantity and quality, limited water and soil nutrient availability (Briske et al., 2015; Brown-Brandl et al., 2006; Gill et al., 2002; Polley et al., 2013).

\section{Sensitivity}

Knowledge of factors that drive and regulate ecological systems are needed in order to understand and predict response to drought. Applying the vulnerability assessment framework within the context of an Ecological Site State and Transition Models (STMs) help us better understand potential impacts and what are the best management strategies for each ecological site. There are 19 ecological sites within MLRA 69 (Figure 10) that differ in production, response to disturbance (e.g. climate variability), management (e.g. prescribed grazing and/or fire) and ability to recover postdisturbance. The ecological sites are grouped based on landform position; breaks, soft breaks, sandy upland, saline upland, loamy upland, lowland and depressions (Schoeneberger and Wysocki, 2012). The vulnerability classes derived in this study (low, medium, or high) are primarily based on landform position, production, rooting depth, soil depth, salt content and land use. Secondary variables that were considered include soil texture, AWC, rock or other fragments and aspect (Table 2) (Appendix - Table A3, A4 and A5). Furthermore, to determine each site's vulnerability to drought we integrated local knowledge of soil scientists, ecological site specialists and rangeland specialists. The vulnerability classes will allow land managers to evaluate how sensitive each class is to drought and support the development of adaptation strategies for conservation planning and implementation. 


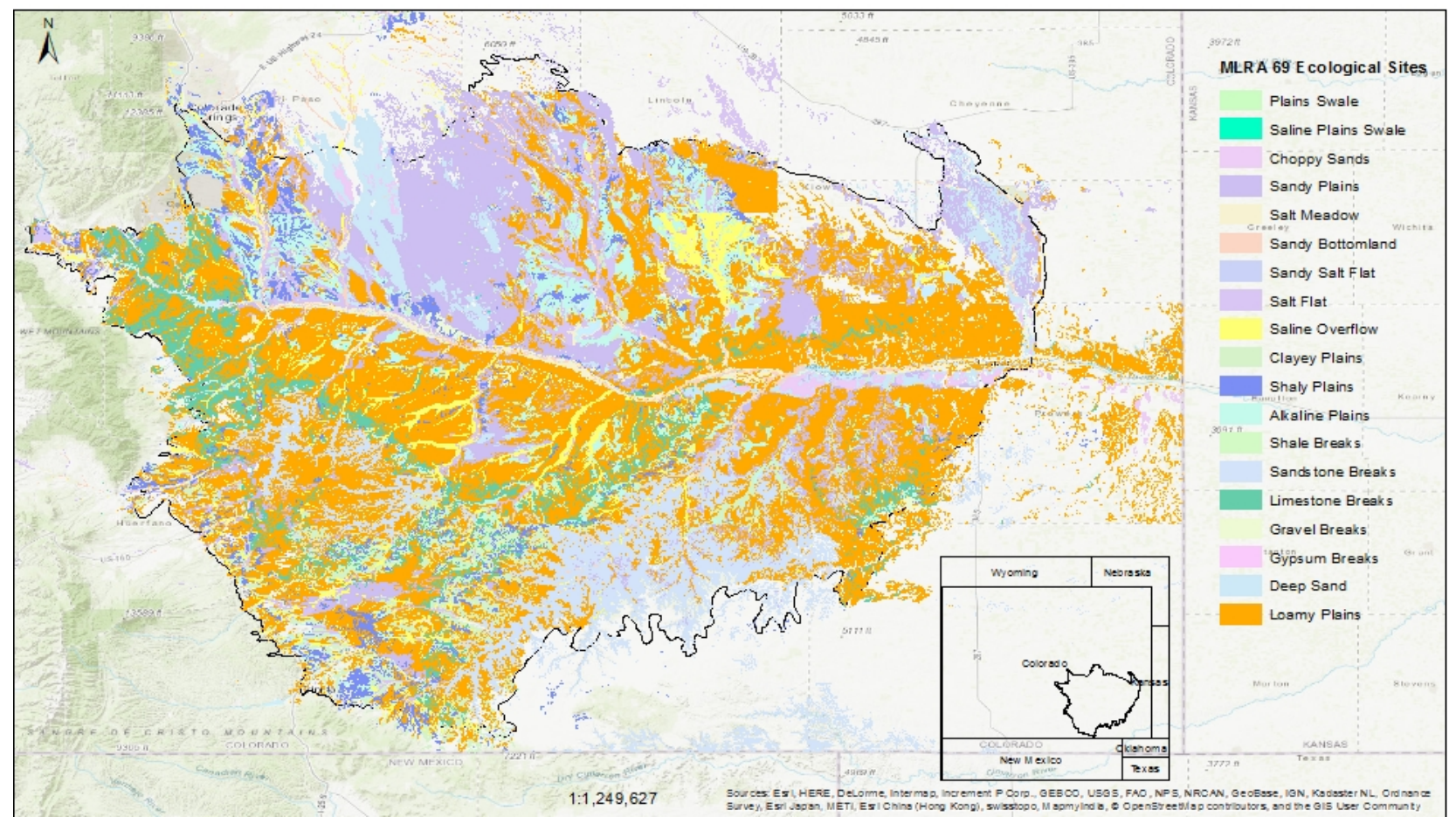

Figure 10. MLRA 69 Ecological Site Extent Map.

Table 2. MLRA 69 Ecological Site Drought Vulnerability Criteria.

\begin{tabular}{|c|c|}
\hline CRITERIA & DESCRIPTION \\
\hline \multicolumn{2}{|l|}{ Primary Variables } \\
\hline Landform Position & $\begin{array}{l}\text { Is the site protected from weather fluctuations (e.g. bottomland vs. } \\
\text { breaks)? Is there potential for high water/wind erosion? }\end{array}$ \\
\hline Production & $\begin{array}{l}\text { Is productivity high enough to mitigate the impacts from drought (e.g. } \\
\text { minimal bare ground)? }\end{array}$ \\
\hline $\begin{array}{l}\text { Vegetation } \\
\text { Rooting Depth }\end{array}$ & $\begin{array}{l}\text { Does the dominate vegetation have greater access to soil water deeper in } \\
\text { profile (pinyon-juniper vs mid/tall grasses vs short grasses)? }\end{array}$ \\
\hline Soil Depth & $\begin{array}{l}\text { Is the site dominated by deep soils (i.e. }>102 \mathrm{~cm} \text { ) or shallow soils (i.e. }<51 \\
\mathrm{~cm} \text { )? }\end{array}$ \\
\hline Salts & Will salt concentration in the soil profile impact plant uptake of water? \\
\hline Land Use & Is the site extensively grazed, tilled, or eroded? \\
\hline \multicolumn{2}{|l|}{ Secondary Variables } \\
\hline Soil Texture & Is the site dominated by loam, clay loam soils or sandy soils? \\
\hline $\begin{array}{l}\text { Available water } \\
\text { Capacity }\end{array}$ & Does the site have a high water holding capacity? \\
\hline Fragments & $\begin{array}{l}\text { Does the site have surface and/or subsurface fragments? Surface fragments } \\
\text { reduce soil temperature and evaporation. Subsurface fragments help } \\
\text { stabilize the site from wind erosion }\end{array}$ \\
\hline Aspect & South facing vs. north facing slope \\
\hline
\end{tabular}


Within the limitations of an ecological site, the current ecological state also determines response to drought of a particular location. Most rangeland in MLRA 69 is in the "at-risk" community phase within the reference state or the "blue-grama community" within the short grass dominated state (Figure 11). The "at risk" phase is defined as the plant community (within any ecological state) most likely to undergo transition to another state if the current disturbance/management continues.
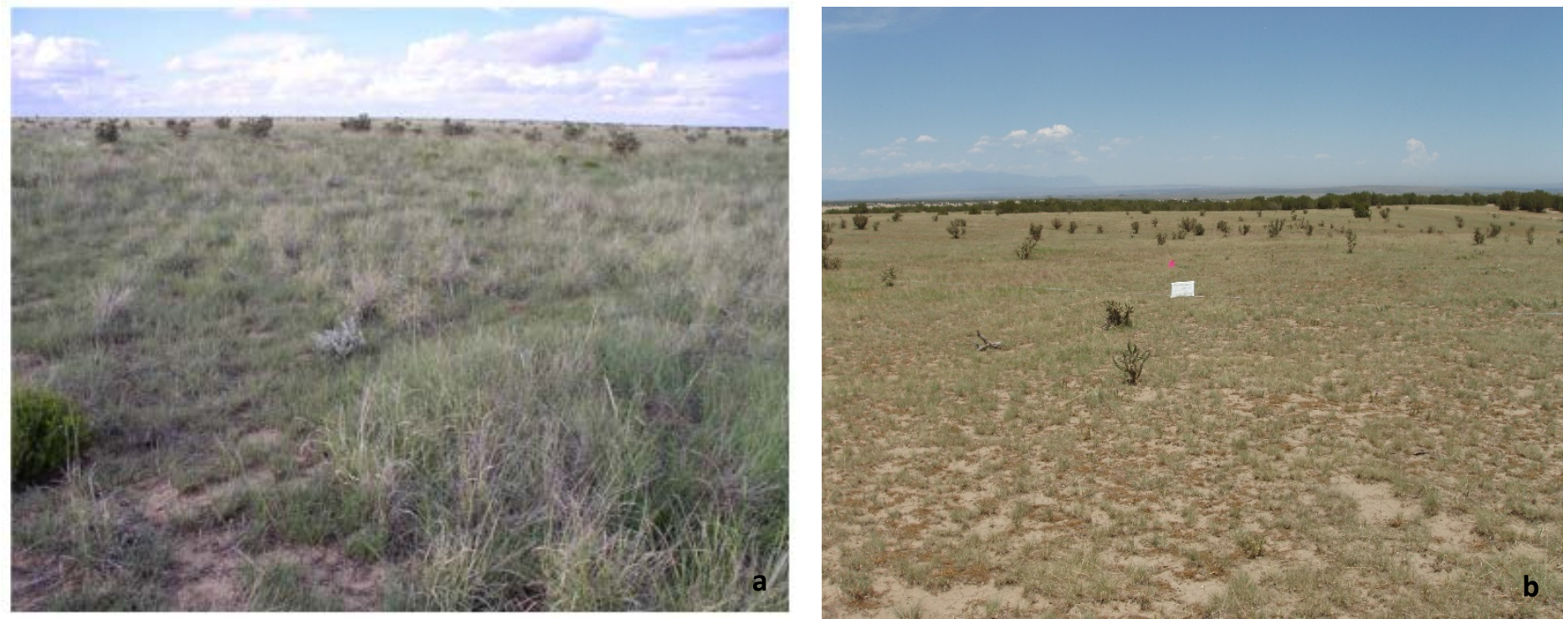

Figure 11. Loamy Plains Ecological Site - a) at risk community and b) short grass dominated state. Photo Courtesy of Kimberly Diller, USDA, NRCS.

For this assessment, we estimated drought sensitivity based on the reference community. For example, the STM below (Figure 12) shows that a site occupied by the at-risk plant community (1.2) will likely transition to the blue-grama dominated community (2.1) if heavy continuous grazing occurs. It is hypothesized that with long-term prescribed grazing the blue-grama community (2.1) can return to the at-risk community (1.2). 
Figure 12. Generalized Conceptual State and Transition Model for Loamy Upland Group in MLRA 69

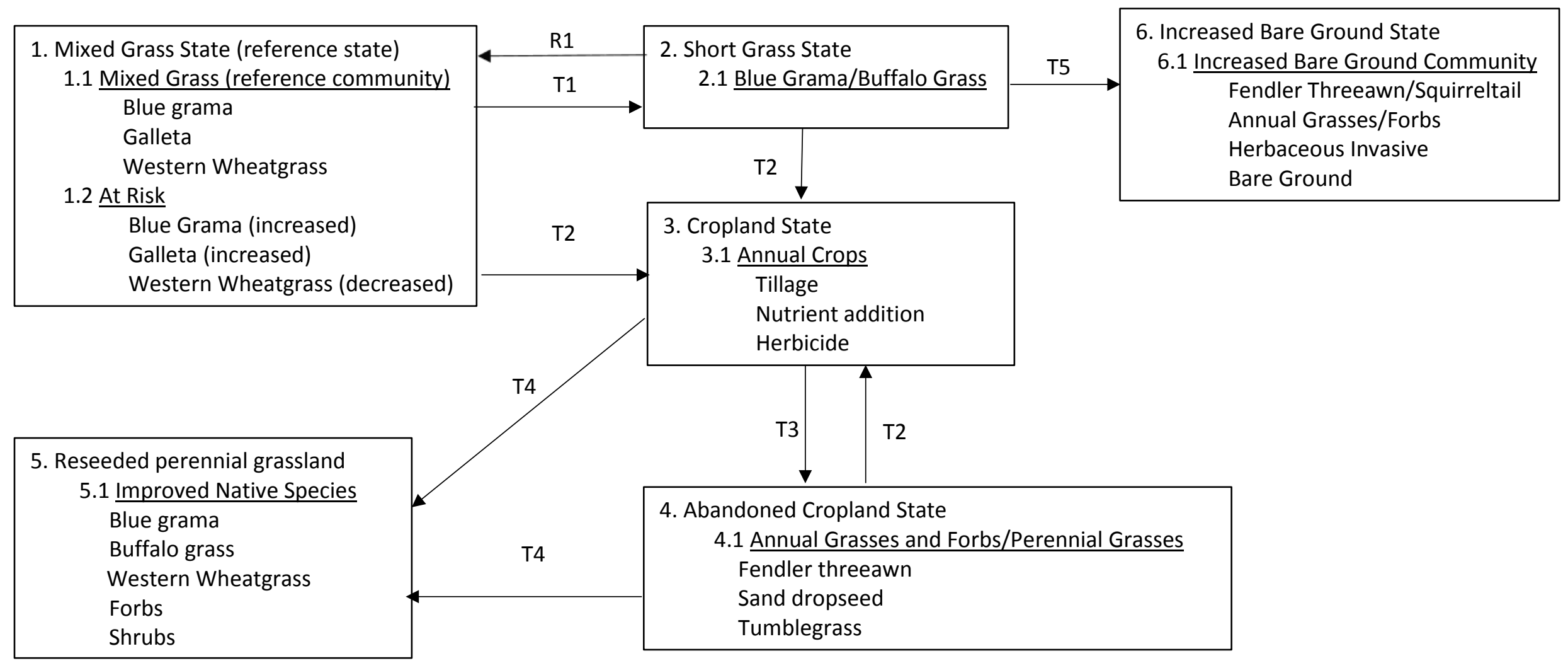

Legend
T1-overgrazing (heavy continuous grazing, poor distribution, inappropriate season)
T2-annual tillage
T3-no tillage, decadal succession
T4-cover crop, range seeding
T5-long-term heavy continuous grazing with or without drought
R1-hypothesis: long-term prescribed grazing; $40+$ years


Each ecological site group was assigned a low, moderate, or high drought vulnerability classification for each ecological state (Table 3). The drought vulnerability classifications can be used as guides for conservationists and landowners when determining management practices.

Table 3. MLRA 69 Ecological Site Class Drought Vulnerability Classes (based on reference community) and Percent Occupied within MLRA.

\begin{tabular}{|l|l|l|l|}
\hline Ecological Site Groups & \multicolumn{3}{|c|}{ Ecological Sites and Percent MLRA 69 Coverage } \\
\hline Breaks & Limestone Breaks (5.93\%) & Sandstone Breaks (7.37\%) & Gravel Breaks (0.94\%) \\
\hline Soft Breaks & Gypsum Breaks (0.08\%) & Shale Breaks (0.69\%) & \\
\hline Sandy Upland & Choppy Sands (0.48\%) & Deep Sand (2.43\%) & Sandy Plains (15\%) \\
\hline Saline Upland & Salt Flat (3.52\%) & Sandy Salt Flat (0.13\%) & Alkaline Plains (5.64\%) \\
\hline Loamy Upland & Loamy Plains (43.39\%) & Clayey Plains (3.93\%) & Shaly Plains (3.94\%) \\
\hline Lowland & Salt Meadow (1.52\%) & Sandy Bottomland (1.4\%) & Saline Overflow (3.75\%) \\
\hline Depressions & Plains Swale (0.14\%) & Saline Plains Swale (0.01\%) & \\
\hline
\end{tabular}

low hoderate high

\section{Breaks Ecological Site Group}

The Breaks Ecological Site group includes the Limestone, Sandstone and Gravel Breaks ecological sites which have a low vulnerability to drought (Table 4). These ecological sites occur on mesas, scarps, ridges, fan remnants and steep hillslopes with a 2-60\% slope range. The limestone and Sandstone Breaks sites consist of shallow soils and the landform position creates greater climatic exposure, however, the deep-rooted vegetation and rock fragments provide stability to the site reducing wind and water erosion impacts. The most common ecological state occupying these sites is the blue grama dominated state where remnants of tall grasses exist, but some root structure and diversity is lost when compared to the reference state making it more vulnerable to drought. Minimal grazing on these sites due to slope and high plant diversity mitigates the effects of drought. Furthermore, resistance to drought is enhanced on sites where pinyon-juniper and shrubs exist due to deeper rooting systems of these plants. The Gravel Breaks ecological site is moderately grazed, but the deeper soils, surface fragments and higher plant productivity mitigate the effects of drought on this site. 


\begin{tabular}{|c|c|c|c|c|}
\hline \multirow{2}{*}{$\begin{array}{l}\text { CRITERIA } \\
\text { Primary } \\
\text { Variables }\end{array}$} & \multicolumn{4}{|c|}{$\begin{array}{l}\text { BREAKS ECOLOGICAL SITE GROUP - } \\
\text { VARIABLE INFLUENCE ON DROUGHT VULNERABILTY }\end{array}$} \\
\hline & $\begin{array}{l}\text { Limestone } \\
\text { Breaks }\end{array}$ & $\begin{array}{l}\text { Sandstone } \\
\text { Breaks }\end{array}$ & $\begin{array}{l}\text { Gravel } \\
\text { Breaks }\end{array}$ & Description \\
\hline $\begin{array}{l}\text { Landform } \\
\text { Position }\end{array}$ & Increases & Increases & Increases & $\begin{array}{l}\text { landform position, steep slopes, higher erosion potential } \\
\text { and greater climatic exposure make this site more } \\
\text { vulnerable to drought }\end{array}$ \\
\hline Production & Decreases & Decreases & Decreases & $\begin{array}{l}\text { high plant productivity and species diversity mitigates } \\
\text { drought impact }\end{array}$ \\
\hline $\begin{array}{l}\text { Vegetation } \\
\text { Rooting } \\
\text { Depth }\end{array}$ & Decreases & Decreases & Decreases & $\begin{array}{l}\text { deep plant roots penetrate deeper into soil profile and } \\
\text { soft parent material accessing water deeper in profile }\end{array}$ \\
\hline Soil Depth & Increases & Increases & decreases & $\begin{array}{l}\text { shallow soils are more vulnerable to drought due to } \\
\text { landform position, greater erosion potential, less } \\
\text { developed soils, and reduced plant available water as } \\
\text { opposed to a more developed deeper soil. }\end{array}$ \\
\hline Salts & $\mathrm{n} / \mathrm{a}$ & $\mathrm{n} / \mathrm{a}$ & $\mathrm{n} / \mathrm{a}$ & minimal salt content to influence site vulnerability \\
\hline Land use & Decreases & Decreases & Decreases & minimal to moderate grazing effects due to slope \\
\hline \multicolumn{5}{|l|}{$\begin{array}{l}\text { Secondary } \\
\text { Variables }\end{array}$} \\
\hline $\begin{array}{l}\text { Soil Surface } \\
\text { Texture }\end{array}$ & Decreases & Decreases & Decreases & $\begin{array}{l}\text { well drained soils with minimal water loss due to } \\
\text { evaporation }\end{array}$ \\
\hline $\begin{array}{l}\text { Available } \\
\text { water } \\
\text { capacity }\end{array}$ & Increases & Increases & Increases & $\begin{array}{l}\text { lower available water capacity due to coarser textured } \\
\text { soils }\end{array}$ \\
\hline Fragments & Decreases & Decreases & Decreases & $\begin{array}{l}\text { surface and subsurface fragments reduce evaporation, } \\
\text { soil temperature and stabilize site from erosion, thus } \\
\text { reducing effects of drought }\end{array}$ \\
\hline Aspect & $\mathrm{n} / \mathrm{a}$ & $\mathrm{n} / \mathrm{a}$ & $\mathrm{n} / \mathrm{a}$ & $\begin{array}{l}\text { sites occur on all aspects; no influence on site } \\
\text { vulnerability }\end{array}$ \\
\hline $\begin{array}{l}\text { Drought } \\
\text { Vulnerability } \\
\text { Rating }\end{array}$ & low & low & low & \\
\hline
\end{tabular}

\section{Soft Breaks Ecological Site Group}

The Soft Breaks Ecological Site group includes the Shale and Gypsum Breaks ecological sites which occur on hillslopes, fan remnants, pediments, scarps and other landform positions on $0-50 \%$ slopes. The parent material is soft and more vulnerable to erosion leading to increased runoff potential. These sites consist of finer textured soils that are shallow $(<50.8 \mathrm{~cm})$ and may occur on steep slopes increasing drought vulnerability due to decreased production, cover and soil moisture. The typical state for this site is a blue-grama dominated state for Shale Breaks ecological site and the reference state for the Gypsum Breaks. Within the reference state these sites have a moderate drought vulnerability classification (Table 5). 


\begin{tabular}{|c|c|c|c|}
\hline CRITERIA & \multicolumn{3}{|r|}{$\begin{array}{l}\text { SOFT BREAKS ECOLOGICAL SITE GROUP - } \\
\text { VARIABLE INFLUENCE ON DROUGHT VULNERABILTY }\end{array}$} \\
\hline $\begin{array}{l}\text { Primary } \\
\text { Variables }\end{array}$ & $\begin{array}{l}\text { Shale } \\
\text { Breaks }\end{array}$ & $\begin{array}{l}\text { Gypsum } \\
\text { Breaks }\end{array}$ & Description \\
\hline $\begin{array}{l}\text { Landform } \\
\text { Position }\end{array}$ & Increases & Increases & $\begin{array}{l}\text { landform position, steep slopes, higher erosion potential and greater } \\
\text { climatic exposure make this site more vulnerable to drought }\end{array}$ \\
\hline Production & Increases & Increases & $\begin{array}{l}\text { low plant productivity, species diversity and cover result in increased } \\
\text { bare ground and evaporation }\end{array}$ \\
\hline $\begin{array}{l}\text { Vegetation } \\
\text { Rooting } \\
\text { Depth }\end{array}$ & Increases & Increases & $\begin{array}{l}\text { shallow to moderate rooting depth limits access to water and nutrients; } \\
\text { less stability }\end{array}$ \\
\hline Soil Depth & Increases & Increases & $\begin{array}{l}\text { shallow soils are more vulnerable to drought due to landform position, } \\
\text { greater erosion potential, less developed soils, and reduced plant } \\
\text { available water as opposed to a more developed deeper soil. }\end{array}$ \\
\hline Salts & Increases & Increases & $\begin{array}{l}\text { presence of gypsum may influence plant available water and } \\
\text { productivity }\end{array}$ \\
\hline Land use & Decreases & Decreases & minimal grazing due to slope \\
\hline \multicolumn{4}{|l|}{$\begin{array}{l}\text { Secondary } \\
\text { Variables }\end{array}$} \\
\hline $\begin{array}{l}\text { Soil Surface } \\
\text { Texture }\end{array}$ & Increases & Increases & $\begin{array}{l}\text { greater erosion and runoff potential due to finer textured soils and soft } \\
\text { parent material; greater potential for evaporation }\end{array}$ \\
\hline $\begin{array}{l}\text { Available water } \\
\text { capacity }\end{array}$ & Decreases & Decreases & $\begin{array}{l}\text { high available water capacity due to finer textured soils to mitigate } \\
\text { drought affects }\end{array}$ \\
\hline Fragments & $\mathrm{n} / \mathrm{a}$ & $\mathrm{n} / \mathrm{a}$ & none to minimal influence on site vulnerability \\
\hline Aspect & $\mathrm{n} / \mathrm{a}$ & $\mathrm{n} / \mathrm{a}$ & sites occur on all aspects; no influence on site vulnerability \\
\hline $\begin{array}{l}\text { Drought } \\
\text { Vulnerability } \\
\text { Rating }\end{array}$ & moderate & moderate & \\
\hline
\end{tabular}

\section{Sandy Upland Ecological Site Group}

The Sandy Upland Ecological Site group includes the Deep Sands, Choppy Sands and Sandy Plains ecological sites which occur on stabilized sand sheets, hillslopes, ridges and blow-outs on slopes less than $25 \%$. These sites are highly productive and consist of tall grasses and sand sagebrush that protect the soil making it less vulnerable to drought. Under stressed conditions the sand sagebrush (Artemisia filifolia) will persist and stabilize the site, however, limited precipitation will lead to increased blowouts on the sandy soils. Although cattle will graze this site, it is somewhat limited due to accessibility. This site class has two different states that are most common for MLRA 69. The sandhill muhly (Muhlenbergia pungens) state is typical for Choppy Sands ecological site and the sand sagebrush (Artemisia filifolia) state for the Deep Sand ecological site. The Sandy Plains ecological site is more vulnerable to drought because it is more extensively grazed and the landform position is more exposed to climate extremes, however this site is highly productive and consist of tall warm season grasses that mitigate drought effects. All three ecological sites within the Sandy Upland ecological group are in the low drought vulnerability class (Table 6). 
Table 6. Sandy Upland Ecological Site Group Variable Index

\begin{tabular}{|c|c|c|c|c|}
\hline \multirow{2}{*}{\begin{tabular}{l}
\multicolumn{1}{c}{ CRITERIA } \\
Primary \\
Variables
\end{tabular}} & \multicolumn{4}{|c|}{$\begin{array}{c}\text { SANDY UPLAND ECOLOGICAL SITE GROUP - } \\
\text { VARIABLE INFLUENCE ON DROUGHT VULNERABILITY }\end{array}$} \\
\hline & $\begin{array}{l}\text { Deep } \\
\text { Sands }\end{array}$ & $\begin{array}{l}\text { Choppy } \\
\text { Sands }\end{array}$ & $\begin{array}{l}\text { Sandy } \\
\text { Plains }\end{array}$ & Description \\
\hline $\begin{array}{l}\text { Landform } \\
\text { Position }\end{array}$ & Increases & Increases & Increases & $\begin{array}{l}\text { run-off site, high erosion potential and greater climatic } \\
\text { exposure make this site more vulnerable to drought }\end{array}$ \\
\hline Production & Decreases & Decreases & Decreases & $\begin{array}{l}\text { high plant productivity and species diversity mitigates } \\
\text { drought impact }\end{array}$ \\
\hline $\begin{array}{l}\text { Vegetation } \\
\text { Rooting } \\
\text { Depth }\end{array}$ & Decreases & Decreases & Decreases & deep plant roots access water deeper in profile \\
\hline Soil Depth & Decreases & Decreases & Decreases & $\begin{array}{l}\text { deep soils with high plant available water deeper in } \\
\text { profile }\end{array}$ \\
\hline Salts & $\mathrm{n} / \mathrm{a}$ & $\mathrm{n} / \mathrm{a}$ & $\mathrm{n} / \mathrm{a}$ & minimal salt content to influence site vulnerability \\
\hline Land use & Increases & Decreases & Increases & low to moderate grazing due to accessibility \\
\hline \multicolumn{5}{|l|}{$\begin{array}{l}\text { Secondary } \\
\text { Variables }\end{array}$} \\
\hline $\begin{array}{l}\text { Soil Surface } \\
\text { Texture }\end{array}$ & Decreases & Decreases & Decreases & $\begin{array}{l}\text { well drained soils with minimal water loss due to } \\
\text { evaporation; coarse soils subject to wind erosion in areas } \\
\text { with bare ground }\end{array}$ \\
\hline $\begin{array}{l}\text { Available water } \\
\text { capacity }\end{array}$ & Increases & Increases & Increases & $\begin{array}{l}\text { lower available water capacity due to coarser textured } \\
\text { soils }\end{array}$ \\
\hline Fragments & $\mathrm{n} / \mathrm{a}$ & $\mathrm{n} / \mathrm{a}$ & $\mathrm{n} / \mathrm{a}$ & no influence on site vulnerability \\
\hline Aspect & $\mathrm{n} / \mathrm{a}$ & $\mathrm{n} / \mathrm{a}$ & $\mathrm{n} / \mathrm{a}$ & $\begin{array}{l}\text { sites occur on all aspects; no influence on site } \\
\text { vulnerability }\end{array}$ \\
\hline $\begin{array}{l}\text { Drought } \\
\text { Vulnerability } \\
\text { Rating }\end{array}$ & low & low & low & \\
\hline
\end{tabular}

\section{Saline Upland Ecological Site Group}

The Saline Upland group includes the Salt Flat, Sandy Salt Flat and Alkaline Plains ecological sites. These sites occur on interfluves, flood plains, terraces, hillslopes, fan remnants and drainage ways on slopes less than $12 \%$. The soils on this site are greater than $102 \mathrm{~cm}$ deep with surface textures ranging from loamy sand to clay. High amounts of salts and sodium occur within the soil profile making these sites more vulnerable to drought. Soils high in salts and sodium affect the soil and root structure and uptake of water by plants leading to decreased productivity. Reduced plant productivity will increase during drought and can lead to increased bare ground. However, the vegetation (i.e. inland salt grass (Distichlis Spicata) and alkaline sacaton (Sporobolus airoides)) on this site are salt tolerant and will persist with limited available moisture. If the site is in a degraded state, it would be more vulnerable to drought and some vegetation (e.g. alkali sacaton) may not recover. The reference plant community is diverse, stable and productive consisting of mid warm and cool season grasses making it less vulnerable to drought. The typical state for the Salt Flat ecological site is the reference state, but has a moderate drought vulnerability rating due to the plant community and high salt content. Furthermore, slick spots and/or bare ground are common on the Salt Flat ecological site, thus increasing the sites vulnerability to drought. Increased plant productivity, deep plant roots, high plant diversity and infiltration rates mitigate the effects of drought on the Sandy Salt Flat ecological site. The Alkaline Plains ecological site is extensively 
grazed. There is potential for evaporation rates to be high due to the soil texture, exposed landform and dominant plant community, making this site more vulnerable to drought (Table 7).

Table 7. Saline Upland Ecological Site Group Variable Drought Sensitivity

\begin{tabular}{|c|c|c|c|c|}
\hline \multirow{2}{*}{\begin{tabular}{l}
\multicolumn{1}{c}{ CRITERIA } \\
Primary \\
Variables
\end{tabular}} & \multicolumn{4}{|c|}{$\begin{array}{l}\text { SALINE UPLAND ECOLOGICAL SITE GROUP - } \\
\text { VARIABLE INFLUENCE ON DROUGHT VULNERABILITY }\end{array}$} \\
\hline & $\begin{array}{l}\text { Salt } \\
\text { Flat }\end{array}$ & $\begin{array}{l}\text { Sandy Salt } \\
\text { Flat }\end{array}$ & $\begin{array}{l}\text { Alkaline } \\
\text { Plains }\end{array}$ & Description \\
\hline $\begin{array}{l}\text { Landform } \\
\text { Position }\end{array}$ & Increases & Decreases & Increases & $\begin{array}{l}\text { slopes are }<12 \% \text {, but sites (except Sandy Salt Flat) do not } \\
\text { receive any additional moisture from adjacent sites and are } \\
\text { exposed to extreme weather conditions (e.g. sun and wind) } \\
\text { slick spots occur Salt Flat ES }\end{array}$ \\
\hline Production & Increases & Decreases & Decreases & $\begin{array}{l}\text { high plant productivity and species diversity mitigates } \\
\text { drought impact }\end{array}$ \\
\hline $\begin{array}{l}\text { Vegetation } \\
\text { Rooting } \\
\text { Depth }\end{array}$ & Increases & Decreases & Increases & $\begin{array}{l}\text { dominant vegetation consists of short, mid or tall warm } \\
\text { season grasses depending on site }\end{array}$ \\
\hline Soil Depth & Decreases & Decreases & Decreases & deep soils with high plant available water deeper in profile \\
\hline Salts & Increases & Increases & Increases & $\begin{array}{l}\text { high salts and sodium affect the soil and root structure and } \\
\text { uptake of water my plants }\end{array}$ \\
\hline Land use & Increases & Increases & Increases & moderate to extensively grazed \\
\hline \multicolumn{5}{|l|}{$\begin{array}{l}\text { Secondary } \\
\text { Variables }\end{array}$} \\
\hline $\begin{array}{l}\text { Soil Surface } \\
\text { Texture }\end{array}$ & Decreases & Decreases & Increases & $\begin{array}{l}\text { well drained soils with minimal water loss due to } \\
\text { evaporation; coarse soils subject to wind erosion; greater } \\
\text { evaporation potential in finer textured soils }\end{array}$ \\
\hline $\begin{array}{l}\text { Available } \\
\text { water } \\
\text { capacity }\end{array}$ & Decreases & Increases & Decreases & lower available water capacity due to coarser textured soils \\
\hline Fragments & $\mathrm{n} / \mathrm{a}$ & $\mathrm{n} / \mathrm{a}$ & $\mathrm{n} / \mathrm{a}$ & no influence on site vulnerability \\
\hline Aspect & $\mathrm{n} / \mathrm{a}$ & $\mathrm{n} / \mathrm{a}$ & $\mathrm{n} / \mathrm{a}$ & sites occur on all aspects; no influence on site vulnerability \\
\hline $\begin{array}{l}\text { Drought } \\
\text { Vulnerability } \\
\text { Rating }\end{array}$ & moderate & low & moderate & \\
\hline
\end{tabular}

\section{Loamy Upland Ecological Site Group}

The Loamy Upland group includes the Loamy, Clayey and Shaly Plains ecological sites. This group is of greatest extent and the most extensively grazed within MLRA 69. These sites can be found on interfluves, hillslopes, fan remnants, drainage ways, terraces and other landform positions. The soil depth ranges from shallow $(<51 \mathrm{~cm})$ to very deep (> 152 $\mathrm{cm}$ ) and the soil surface texture is highly variable from sandy loam to clay. These sites are located in an upland landform position where they are not sheltered from weather extremes and do not receive any additional moisture from adjacent sites. Majority of the reference community is grass and forbs and is heavily grazed by livestock. Grasses are sod bound resulting in more water being lost to evapotranspiration than infiltrating through the soil. Short grass dominated state is the typical state. The ecological sites within this group have a medium vulnerability rating because of the landform position, vegetation and land use (Table 8 ). 


\begin{tabular}{|c|c|c|c|c|}
\hline \multirow{2}{*}{$\begin{array}{l}\text { CRITERIA } \\
\text { Primary } \\
\text { Variables }\end{array}$} & \multicolumn{3}{|c|}{ BREAKS ECOLOGICAL SITE GROUP } & \multirow{2}{*}{$\begin{array}{l}\text { VULNERABILITY JUSTIFICATION } \\
\text { Descriptor }\end{array}$} \\
\hline & $\begin{array}{l}\text { Loamy } \\
\text { Plains }\end{array}$ & $\begin{array}{l}\text { Clayey } \\
\text { Plains }\end{array}$ & $\begin{array}{l}\text { Shaly } \\
\text { Plains }\end{array}$ & \\
\hline $\begin{array}{l}\text { Landform } \\
\text { Position }\end{array}$ & Increases & Increases & Increases & $\begin{array}{l}\text { slopes are }<25 \% \text {, but sites do not receive any additional } \\
\text { moisture from adjacent sites and are exposed to extreme } \\
\text { weather conditions (e.g. sun and wind) }\end{array}$ \\
\hline Production & Increases & Increases & Increases & $\begin{array}{l}\text { plant production and species diversity is minimal due to } \\
\text { landform position and land use }\end{array}$ \\
\hline $\begin{array}{l}\text { Vegetation } \\
\text { Rooting } \\
\text { Depth }\end{array}$ & Increases & Increases & Increases & $\begin{array}{l}\text { dominant vegetation consists of short-mid season grasses } \\
\text { that are extensively grazed }\end{array}$ \\
\hline Soil Depth & Decreases & Decreases & Increases & $\begin{array}{l}\text { shallow soils are more vulnerable to drought due to } \\
\text { landform position, greater erosion potential, less developed } \\
\text { soils, and reduced plant available water as opposed to a } \\
\text { more developed deeper soil. }\end{array}$ \\
\hline Salts & $\mathrm{n} / \mathrm{a}$ & $\mathrm{n} / \mathrm{a}$ & $\mathrm{n} / \mathrm{a}$ & minimal salt content that influences site vulnerability \\
\hline Land use & Increases & Increases & Increases & extensively grazed \\
\hline \multicolumn{5}{|l|}{$\begin{array}{l}\text { Secondary } \\
\text { Variables }\end{array}$} \\
\hline $\begin{array}{l}\text { Soil Surface } \\
\text { Texture }\end{array}$ & Decreases & Increases & Increases & $\begin{array}{l}\text { increased runoff and evaporation potential on sites with } \\
\text { finer textured soils }\end{array}$ \\
\hline $\begin{array}{l}\text { Available } \\
\text { water } \\
\text { capacity }\end{array}$ & Decreases & Decreases & Decreases & $\begin{array}{l}\text { typically sites with higher clay content would be less } \\
\text { vulnerable to drought due to higher available water capacity }\end{array}$ \\
\hline Fragments & $\mathrm{n} / \mathrm{a}$ & $\mathrm{n} / \mathrm{a}$ & $\mathrm{n} / \mathrm{a}$ & no influence on site vulnerability \\
\hline Aspect & $\mathrm{n} / \mathrm{a}$ & $\mathrm{n} / \mathrm{a}$ & $\mathrm{n} / \mathrm{a}$ & sites occur on all aspects; no influence on site vulnerability \\
\hline $\begin{array}{l}\text { Drought } \\
\text { Vulnerability } \\
\text { Rating }\end{array}$ & moderate & moderate & moderate & \\
\hline
\end{tabular}

\section{Lowland Ecological Site Group}

The Lowland Ecological group includes the Sandy Bottomland, Saline Overflow and Salt Meadow ecological sites (Table 9). These sites typically occur on floodplains and are gently sloping with a 0-5\% slope. This group receives additional moisture from adjacent areas and the Salt Meadow site may be influenced by a shallow water table or wetland. The soils for this group are very deep (>152 cm) and surface textures vary greatly from sandy to silty clay soils. Sites that have a sandy surface texture are subject to wind erosion. However, wind erosion is minimal due to the landform position and production amounts. Although the Saline Overflow contains salts, the presence of inland salt grass should reduce drought impacts. The typical state is the sand sagebrush state (Sandy Bottomland site) or the short grass dominated state (Saline Overflow site). In the Sandy Bottomland site, the plant community diversity is reduced as the sand sagebrush increases, however, the site is also stabilized as the sand sagebrush expands it range. The grass dominated state within the Sandy Bottomland site includes short, mid and tall grasses, but forbs are often reduced as a result of 
chemical input used to control noxious weeds. The ecological sites within this group class have a low drought vulnerability classification due to the very deep soils, low slope, and landform position.

The Salt Meadow ecological site occurs on stream terraces, flood plains, fans and swales where multiple layers of deposition have occurred over time resulting in different soil textures and percent rock fragments. Extensive grazing without providing time for adequate recovery could push this site across the threshold into a state with greater amounts of surface salts leading to a higher drought vulnerability. The typical state for this site is the reference state which includes inland saltgrass and decreased amounts of mid-tall grasses. The soil texture, depth, landform positon, and available water sources give this site a low drought vulnerability when in the reference state.

Table 9. Lowlands Ecological Site Group Variable Index

\begin{tabular}{|c|c|c|c|c|}
\hline \multirow{2}{*}{$\begin{array}{l}\text { CRITERIA } \\
\text { Primary } \\
\text { Variables }\end{array}$} & \multicolumn{4}{|c|}{$\begin{array}{l}\text { LOWLANDS ECOLOGICAL SITE GROUP - } \\
\text { VARIABLE INFLUENCE ON SITE VULNERABILITY }\end{array}$} \\
\hline & $\begin{array}{c}\text { Sandy } \\
\text { Bottomland }\end{array}$ & $\begin{array}{l}\text { Saline } \\
\text { Overflow }\end{array}$ & $\begin{array}{c}\text { Salt } \\
\text { Meadow }\end{array}$ & Description \\
\hline $\begin{array}{l}\text { Landform } \\
\text { Position }\end{array}$ & Decreases & Decreases & Decreases & $\begin{array}{l}\text { gentle slopes, receives additional moisture } \\
\text { from adjacent areas and shallow water table } \\
\text { present at some sites mitigate drought } \\
\text { affects }\end{array}$ \\
\hline Production & Decreases & Decreases & Decreases & $\begin{array}{l}\text { high plant production and species diversity } \\
\text { mitigate drought affects }\end{array}$ \\
\hline $\begin{array}{l}\text { Vegetation } \\
\text { Rooting } \\
\text { Depth }\end{array}$ & Decreases & Decreases & Decreases & $\begin{array}{l}\text { deep plant roots access water deeper in } \\
\text { profile mitigate drought affects }\end{array}$ \\
\hline Soil Depth & Decreases & Decreases & Decreases & $\begin{array}{l}\text { deep soils with plant available water deeper } \\
\text { in profile mitigate drought affects }\end{array}$ \\
\hline Salts & Decreases & Increases & Increases & $\begin{array}{l}\text { presence of salts affect the soil structure } \\
\text { and uptake of water my plants }\end{array}$ \\
\hline Land use & Increases & Increases & Increases & moderate grazing by livestock \\
\hline \multicolumn{5}{|l|}{$\begin{array}{l}\text { Secondary } \\
\text { Variables }\end{array}$} \\
\hline $\begin{array}{l}\text { Soil Surface } \\
\text { Texture }\end{array}$ & Increases & Decreases & Increases & $\begin{array}{l}\text { well drained soils with minimal water loss } \\
\text { due to evaporation; coarse soils subject to } \\
\text { wind erosion }\end{array}$ \\
\hline $\begin{array}{l}\text { Available } \\
\text { water } \\
\text { capacity }\end{array}$ & Increases & Decreases & Decreases & $\begin{array}{l}\text { greater available water capacity in finer } \\
\text { textured soils, however, it is highly variable } \\
\text { within sites due to landform position. }\end{array}$ \\
\hline Fragments & $\mathrm{n} / \mathrm{a}$ & $\mathrm{n} / \mathrm{a}$ & $\mathrm{n} / \mathrm{a}$ & no influence on site vulnerability \\
\hline Aspect & $\mathrm{n} / \mathrm{a}$ & $\mathrm{n} / \mathrm{a}$ & $\mathrm{n} / \mathrm{a}$ & $\begin{array}{l}\text { sites occur on all aspects; no influence on } \\
\text { site vulnerability }\end{array}$ \\
\hline $\begin{array}{l}\text { Drought } \\
\text { Vulnerability } \\
\text { Rating }\end{array}$ & low & low & low & \\
\hline
\end{tabular}


The Depressions Ecological Group include the Plains Swale and the Saline Plains Swale ecological sites. These ecological sites occur on closed depressions and have very deep soils. These sites receive additional moisture from adjacent sites, but are high in clay resulting in low infiltration and higher potential for water loss through evaporation making them more vulnerable to drought (Table 10).

Table 10. Depressions Ecological Site Group Variable Index

\begin{tabular}{|c|c|c|c|}
\hline \multirow{2}{*}{\begin{tabular}{l}
\multicolumn{1}{c}{ CRITERIA } \\
Primary \\
Variables
\end{tabular}} & \multicolumn{3}{|c|}{$\begin{array}{l}\text { DEPRESSIONS ECOLOGICAL SITE GROUP - } \\
\text { VARIABLE INFLUENCE ON SITE VULNERABILITY }\end{array}$} \\
\hline & $\begin{array}{l}\text { Plains } \\
\text { Swale }\end{array}$ & $\begin{array}{l}\text { Saline Plains } \\
\text { Swale }\end{array}$ & Description \\
\hline $\begin{array}{l}\text { Landform } \\
\text { Position }\end{array}$ & Decreases & Decreases & $\begin{array}{l}\text { receives additional moisture from adjacent areas that mitigate } \\
\text { drought affects }\end{array}$ \\
\hline Production & Increases & Increases & $\begin{array}{l}\text { sod bound vegetation and minimal species diversity to resist } \\
\text { drought affects }\end{array}$ \\
\hline $\begin{array}{l}\text { Vegetation } \\
\text { Rooting } \\
\text { Depth }\end{array}$ & Increases & Increases & $\begin{array}{l}\text { dominant vegetation is short and mid warm season grasses that } \\
\text { may not access water deeper in the soil profile }\end{array}$ \\
\hline Soil Depth & Decreases & Decreases & $\begin{array}{l}\text { deep soils with plant available water deeper in profile mitigate } \\
\text { drought affects }\end{array}$ \\
\hline Salts & $\mathrm{n} / \mathrm{a}$ & Increases & $\begin{array}{l}\text { presence salts affect the soil structure and uptake of water my } \\
\text { plants }\end{array}$ \\
\hline Land use & Increases & Increases & moderate grazing by livestock \\
\hline \multicolumn{4}{|l|}{$\begin{array}{l}\text { Secondary } \\
\text { Variables }\end{array}$} \\
\hline $\begin{array}{l}\text { Soil Surface } \\
\text { Texture }\end{array}$ & Increases & Increases & $\begin{array}{l}\text { high clay content that reduces infiltration and increases moisture } \\
\text { loss to evaporation }\end{array}$ \\
\hline $\begin{array}{l}\text { Available water } \\
\text { capacity }\end{array}$ & Decreases & Decreases & greater available water capacity due to finer textured soils \\
\hline Fragments & $\mathrm{n} / \mathrm{a}$ & $\mathrm{n} / \mathrm{a}$ & no influence on site vulnerability \\
\hline Aspect & $\mathrm{n} / \mathrm{a}$ & $\mathrm{n} / \mathrm{a}$ & sites occur on all aspects; no influence on site vulnerability \\
\hline $\begin{array}{l}\text { Drought } \\
\text { Vulnerability } \\
\text { Rating } \\
\end{array}$ & moderate & moderate & \\
\hline
\end{tabular}

\section{Potential Impact}

Ecological Sites in MLRA 69 are representative of the shortgrass prairie ecosystem as a whole. An evolutionary history of relatively heavy grazing by large native herbivores has resulted in vegetation assemblages that are generally resistant to contemporary livestock grazing practices (Milchunas et al., 1988), especially in terms of response of plant community attributes such as species composition, net primary productivity and nutrient cycling (Milchunas et al., 1998). Therefore, given the minor impacts that livestock grazing management would have on longer-term behavior of these Ecological Sites, we are focusing our VA on the shorter-term direct impacts of drought on annual forage production and the 
indirect effects of changes in plant species composition that reduce forage production. In MLRA 69, total annual production is highly dependent on the distribution of precipitation and its effects on soil moisture. During droughts, total annual production declines, affecting grazing management decisions (Table 11).

Table 11. MLRA 69 Ecological Site Total Annual Production and Stocking Rates (based on reference community).

\begin{tabular}{|c|c|c|c|c|c|c|}
\hline \multirow[t]{2}{*}{ Ecological Site } & \multicolumn{3}{|c|}{ Total Annual Production (Ibs/ac) } & \multicolumn{3}{|c|}{ Stocking Rate (acre/aum) } \\
\hline & Low & Average & High & Low & Average & High \\
\hline Limestone Breaks & 350 & 600 & 900 & 10.43 & 6.08 & 4.06 \\
\hline Sandstone Breaks & 600 & 1000 & 1600 & 6.08 & 3.65 & 2.28 \\
\hline Gravel Breaks & 350 & 750 & 1200 & 10.43 & 4.87 & 3.04 \\
\hline Gypsum Breaks & 150 & 300 & 500 & 24.33 & 12.17 & 7.30 \\
\hline Shale Breaks & 150 & 300 & 700 & 24.33 & 12.17 & 5.21 \\
\hline Choppy Sands & 600 & 1150 & 1400 & 6.08 & 3.17 & 2.61 \\
\hline Deep Sand & 900 & 1500 & 2000 & 4.06 & 2.43 & 1.83 \\
\hline Sandy Plains & 950 & 1500 & 2000 & 3.84 & 2.43 & 1.83 \\
\hline Salt Flat & 400 & 1000 & 1400 & 9.13 & 3.65 & 2.61 \\
\hline Sandy Salt Flat & 700 & 1300 & 2000 & 5.21 & 2.81 & 1.83 \\
\hline Alkaline Plains & 500 & 1200 & 1500 & 7.30 & 3.04 & 2.43 \\
\hline Loamy Plains & 500 & 1100 & 1600 & 7.30 & 3.32 & 2.28 \\
\hline Clayey Plains & 300 & 750 & 1100 & 12.17 & 4.87 & 3.32 \\
\hline Shaly Plains & 300 & 750 & 1100 & 12.17 & 4.87 & 3.32 \\
\hline Salt Meadow & 1500 & 2600 & 3700 & 2.43 & 1.40 & 0.99 \\
\hline Sandy Bottomland & 1000 & 1600 & 2200 & 3.65 & 2.28 & 1.66 \\
\hline Saline Overflow & 750 & 1500 & 2500 & 4.87 & 2.43 & 1.46 \\
\hline Plains Swale & 500 & 1100 & 1700 & 7.30 & 3.32 & 2.15 \\
\hline Saline Plains Swale & 650 & 1350 & 2100 & 5.62 & 2.70 & 1.74 \\
\hline
\end{tabular}

*Plant productivity at below average, average, and above average precipitation and temperature conditions

* On site visit is necessary to determine stocking rates as site conditions and stocking rate will vary

*Stocking rate based on $1000 \mathrm{lb}$ cow and 25\% Harvest Efficiency Method

In addition to the effects of livestock grazing, droughts are important ecological drivers, significantly influencing the composition and distribution of rangeland plant communities. Severe drought can lead to local extirpation in areas where the recolonization potential of the site is low (Samson et al., 2004). Both abiotic (Ecological Site) and biotic (ecological state) can define how a site will respond to drought. Although heavy grazing can influence plant community dynamics, climate variability has a greater effect on plant community and productivity in arid and semi-arid environments (Biondini et al., 1998). In areas such as MLRA 69, blue grama often becomes the dominant species during a drought as buffalograss is more sensitive to drier conditions. However, buffalograss is resilient once precipitation 
returns. During a short term moderate drought (i.e. not severe or prolonged), moderate grazing will allow the least drought-resistant species (e.g. buffalograss) to persist (Vose et al., 2016).

The 2002 drought was the worst single year drought in over 100 years for southeast Colorado. In an ungrazed Salt Flat Ecological Site rabbitbrush/greasewood mixed grassland community near Pueblo, CO, shrub cover increased more than $30 \%$ after the 2002 drought whereas grass cover (dominated by blue grama) declined $45 \%$ from pre-drought conditions (Rondeau et al., 2013). Notably, there were generally no or minor changes in density in either shrubs or grasses and no changes in bare ground as a result of the drought. Even though this blue grama dominated community shifted to a rabbitbrush dominated community post-drought, the minor changes in plant frequency of all species indicate capacity for recovery, especially if grazing pressure is minimal (Rondeau et al., 2013). On this ecological site, with species common to other sites in the MLRA, drought, in the absence of grazing, resulted in a significant shift in lifeform and species cover dominance. However, the relatively small changes in plant frequency, indicate opportunities for recovery, albeit on a decadal scale. In both the immediate and near term, the response to drought is clearly stocking rate reduction.

Less frequent but more intense precipitation events affecting water availability and growing season will have impacts on biogeochemical cycling in rangelands (Austin et al., 2004; Dijkstra et al., 2010). A shift in plant species, community composition and ecological state can influence the soil C and $\mathrm{N}$ cycles in a semi-arid ecosystem (Epstein et al., 1998). Plant communities differ in productivity, $\mathrm{N}$ use efficiencies and litter quality which can affect the $\mathrm{N}$ dynamics of a system. An increase in warm season plants may reduce the availability of $\mathrm{N}$ which can influence plant community structure. Epstein et al (1998) showed that cool season grasses had greater rates of net $\mathrm{N}$ mineralization and $\mathrm{N}$ retention when compared to warm season grasses. Drought can impact the $\mathrm{C}$ cycle in rangelands with potential feedbacks to climate change. Approximately one-third of terrestrial $\mathrm{C}$ is stored in rangelands, but drought may diminish $\mathrm{C}$ sinks and enhance $C$ sources as plant production is more sensitive to drought than microbial respiration (Canarini et al., 2016; Hoover and Rogers, 2016). A decrease in precipitation has shown to directly impact plant productivity whereas a reduction in microbial respiration can be driven by loss of soil moisture and lack of C inputs (Hoover and Rogers, 2016; Shi et al., 2014). Changes in amount, intensity, and frequency of precipitation events may also affect the potential for invasions, as species that are better adapted to an altered climate may have an advantage over native vegetation (Mack et al., 2000). Changes in plant functional groups affect the availability of soil resources, but resource availability and timing of precipitation can also affect the plant community composition. Drought reduces forage and water available for livestock grazing. The reduction in vegetative cover may lead to wind and water erosion as well as increase occurrence and intensity of wildfires, insect outbreaks, and invasion of non-native plant species. Approximately $81 \%$ of pasture and rangelands in Colorado were rated either "poor" or "very poor" during the 2012 drought, leading hay prices to triple. Furthermore, hay production was limited to $10-50 \%$ of average causing buyers to pay extra to have hay trucked in from across the country. The extreme drought of 2012 led to the highest recorded evapotranspiration rates in Colorado in the last 20 years as well as an elevated wildfire season responsible for an estimated 450 million dollars in insured losses and 5 fatalities (Ryan and Doesken, 2013).

\section{Adaptive Capacity}

Management actions to adapt to projected shifts in climate can mitigate the ecological and socio-economic impacts on rangeland systems. Applying adaptive management strategies before, during and after a drought are vital to maintain a functioning ecosystem and to ensure an economic return. The highly variable weather patterns and forage production across rangelands requires dynamic drought and grazing management plans that are capable of adapting to seasonal change. When considering adaptive management strategies, Joyce et al. (2013) recommends taking a systematic approach to evaluate what tools to use before, during, and after drought. Adaptive management should include flexibility to minimize the effects of a natural disaster at multiple levels; enterprise or management level, ecological level and the human/social level (Table 12). Being able to adapt to a changing climate involves constantly monitoring weather conditions and patterns as weather varies from region to region and across rangelands. 
- Enhance drought management plan

- Reduce stocking rate

- Do not exceed site's carrying capacity - 50 acres per AU/year

- Implement rotational grazing plan that allows adequate rest for native plants - (30-90 days depending on time of year and precipitation received).

- Evaluate animal size and keep herd composition flexible

- Change species from cattle to sheep or goats or heat tolerant cattle

- Know forage supply and demand before, during and after drought

- Consider alternative feeds for cattle (i.e. high grain diet fed in drylot or semi-confinement)

- Evaluate alternate income sources

- Do not graze during the dormant season and maintain minimal stubble heights through winter

- Do not graze when pastures are wet

- Delay grazing until plants reach 5-6 inches in height

- Provide shade for cattle and minimize distance between water sources
- Become familiar with ecological sites and their state \& transition models to assist with management strategy

- Know how sensitive your site is to drought

- Enhance invasive species monitoring and control

- Monitor key forage species and when to graze

- Maintain as much carryover forage as possible.

- Monitor how much forage is left after grazing, not how much has been consumed

- Properly grazed pasture will have an uneven look

- Monitor bare ground areas

- Maintain cover to protect the soil

- Increase knowledge on rangeland/ soil health
- Willingness to adopt change

- Increase knowledge on climate variability

- Be flexible and willing to implement different management strategies

- Understand the socio-ecological impacts of drought

- Work with local, state and federal government regarding conservation practices

- Attend grazing and drought workshops

- Engage with USDA Southwest Climate Hub regarding climate informed decision making and available climate resources

- Develop social networks to enhance knowledge on different management strategies 
Enterprise - One of the most important adaptive strategies in rangelands is to allow adequate rest and recovery of vegetation. In normal years in Colorado, 30-45 days is recommended during May and June and 60-90 days during JulyOctober for a pasture to recover after grazing. More recovery days are necessary during drought years (Cook et al., 2017). Providing longer rest periods during drought can be accomplished by either increasing the number of pastures or decreasing the length of grazing time. The time needed for adequate regrowth depends on plant species (cool vs warm season), climate, soil moisture and time of year. Forages must have enough leaf area left after grazing to allow the plant to regrow and replenish their root and stem base food reserves. Plants should not be grazed during the dormant season and grazing should be delayed until plants reach minimum grazing heights (Table 13). Reducing stocking rate is the most important adaptive strategy when coping with drought in rangelands as overgrazing can result in desirable forages being replaced by undesirable weeds like Russian thistle (Salsola kali), cheat grass (Bromus tectorum), kochia (Bassia prostrata) and bindweed (Convolvulus arvensis). Under normal precipitation and temperature conditions, approximately 50 acres is needed to support 1 AU/year within MLRA 69. However, when precipitation is $75 \%$ of average or lower for at least several months, drought conditions exist and grazing management should be conservative during both the drought period and the growing season following a drought (Cook et al., 1997). Understanding site potential (e.g. sensitivity to drought) and knowing a site's carrying capacity is an important tool for grazing management. Hart and Carpenter (2001) recommend that breeding stocks should only represent $50-70 \%$ of the total carrying capacity in areas where drought is common as conservative stocking rates will provide adequate carryover forage that can be used when drought occurs. Another way to adapt to elevated temperatures and reduced precipitation is changing cattle to a more heat tolerant breed such as Brahman or changing livestock species (from cattle to sheep/goats) to minimize forage uptake. Providing shade and minimizing distance between water sources is also recommended as a way to alleviate heat stress on livestock. Alternative feeding options such as a high grain diet fed diet should be considered during a drought when forage is limited (LeValley, 2014). A flexible and well thought out drought plan that includes an evaluation of forage supply and demand, rotational grazing, flexible stocking rate, adequate rest and recovery should be conducted before, during and after a drought. Hart and Carpenter (2001) suggests that the best time to develop a drought management plant is during non- drought years. Willingness to change enterprise structure such as shifting from livestock production to ecotourism, hunting, or wind energy may be necessary if the traditional operation is no longer economically viable (Joyce et al., 2013).

Table 13. Protective Grazing heights for Key Forage Species in Colorado (Cook et al., 2017)

\begin{tabular}{lcc}
\hline $\begin{array}{l}\text { Dominant } \\
\text { Forage Species }\end{array}$ & $\begin{array}{c}\text { Minimum } \\
\text { Starting Height } \\
(\mathrm{cm})\end{array}$ & $\begin{array}{c}\text { Minimum } \\
\text { Grazing Height } \\
(\mathrm{cm})\end{array}$ \\
\hline Alkali sacaton (Sporobolus airoides) & 15.2 & 10.2 \\
Blue grama (Bouteloua gracilis) & 7.6 & 5.1 \\
Little bluestem (Schizachyrium scoparium) & 15.2 & 10.2 \\
Orchard grass (Dactylis glomerata) & 12.7 & 7.6 \\
Russian wildrye (Psathyrostachys juncea) & 12.7 & 7.6 \\
Sand bluestem (Andropogon hallii), Big bluestem & & 15.2 \\
(Andropogon gerardii) & 20.3 & 10.2 \\
Sideoats grama (Bouteloua curtipendula) & 15.2 & 7.6 \\
Smooth brome (Bromus inermis) & 12.7 & 15.2 \\
Switchgrass (Panicum virgatum) & 20.3 & \\
Wheatgrasses (Pubescent, Intermediate, Crested & & 7.6 \\
(Agropyron cristatum), or Siberian (Agropyron & 12.7 & \\
fragile)) & &
\end{tabular}




\begin{tabular}{lcc}
\hline $\begin{array}{l}\text { Dominant } \\
\text { Forage Species }\end{array}$ & $\begin{array}{c}\text { Minimum } \\
\text { Starting Height } \\
(\mathrm{cm})\end{array}$ & $\begin{array}{c}\text { Minimum } \\
\text { Grazing Height } \\
\text { (cm) }\end{array}$ \\
\hline $\begin{array}{l}\text { Wheatgrasses (Western (Pascopyrum smithii), } \\
\begin{array}{l}\text { Bluebunch (Pseudoroegneria spicata), Slender } \\
\text { (Elymus trachycaulus), or Thickspike (Agropyron }\end{array}\end{array}$ & & \\
lanceolatus) ) & 15.2 & 10.2 \\
Wheatgrass, tall (Thinopyrum ponticum) & 20.3 & 15.2 \\
Yellow indiangrass (Sorghastrum nutans) & 20.3 & 15.2 \\
Tufted hair grass (Deschampsia cespitosa) & 15.2 & 10.2 \\
Nebraska sedge (Carex nebrascensis) & 15.2 & 10.2 \\
Prairie cordgrass (Spartina pectinata) & 20.3 & 12.7 \\
Prairie sandreed (Calamovilfa longifolia) & 20.3 & 12.7 \\
Tall fescue (Schedonorus arundinaceus) & 12.7 & 7.6 \\
\hline
\end{tabular}

Ecological - Projected changes in climate in the western Great Plains are likely to increase the vulnerability of rangeland ecosystems to drought, leading to short term reductions in forage production and longer term transitions from one ecological state to another. Knowledge of ecological sites and ecological states affect drought sensitivity will support the development of a site-specific drought management plan. Landowners can influence how ecosystems respond to drought through management actions. When developing adaptive management strategies for livestock grazing, it is important to know the forage supply and demand in order to maintain as much carryover forage as possible (Cook et al., 1997; Hart and Carpenter, 2001). Landowners should monitor key forage species and know when to start/stop grazing as well as how much forage is left after grazing (Cook et al., 1997). Continuous monitoring of vegetation productivity, invasive species and bare ground will help increase ecosystem resilience. Economic returns and ecological integrity are linked to vegetative resources, therefore, careful consideration of vegetation condition is necessary, before, during, and after droughts.

Human/Social Organization - Enhancing adaptive capacity and facilitating social learning across multiple socialecological levels is a critical component of confronting climate change on rangelands. Individuals, institutions and government agencies must be willing to adopt change and increase awareness about climate variability and its environmental and economic effects. Adaptation to climate variability on a socio-ecological scale includes working with government agencies regarding conservation practices, as well as Universities, conservation districts, and the USDA Climate Hubs to gain knowledge about available climate adaptation resources and adaptive management options. The USDA - Natural Resources Conservation Service (NRCS) provides conservation planning and programs to landowners to assist with grazing management. The NRCS conservation planning process is a nine step process (https://www.nrcs.usda.gov/wps/portal/nrcs/main/national/technical/cp/) that develops and implements plans that protect, conserve, and enhance natural resources. Landowners can apply for NRCS programs once the conservation plan is complete. The two main conservation programs available for rangeland conservation are the Environmental Quality Incentive Program (EQIP) and Conservation Stewardship Program (CSP). Landowners can receive assistance for stock tanks, fencing, pipeline and wells that support conservation practices through EQIP. Increasing the number of stock tanks will minimize heat stress on cattle by reducing the distant between water sources and installing fencing encourages rotational grazing practices. The CSP provides grazing plans that will improve forage and rangeland condition, shrub management and/or improve rangeland wildlife habitat. Other resources include the USDA Climate Hubs which provide data, tools and assessments to support climate informed decision making by landowners. Most adaptive management plans include management practices that mitigate the impacts of climate change, but few plans 
consider the socio-economic incentives or human behavior toward management to promote ecosystem resilience. The availability of information, experience and training, social and economic incentives and resources is required to implement adaptive management at the socio-economic level (Joyce et al., 2013).

\section{Summary}

Increased climate variability, including more frequent and intense drought, is projected for the southwestern United States. The projected change in climate will vary depending on geographic location. Vulnerability assessments and adaptation strategies are needed at the local level to mitigate the effects of climate change on rangelands. Ecological sites and their associated state and transition models are tools to help land managers implement and evaluate responses. Being aware of the rangeland condition and ecological site's sensitivity to drought can mitigate the effects of drought at a site specific level. Incorporating enterprise, ecological and social/human organization strategies into an adaptive management plan will mitigate the effects of drought which is critical to the social and ecological stability in the region.

\section{References}

Abatzoglou, J., 2017. AgClimate Atlas. climate.northwestknowledge.net (accessed 3.16.17).

Austin, A.T., Yahdjian, L., Stark, J.M., Belnap, J., Porporato, A., Norton, U., Ravetta, D.A., Schaeffer, S.M., 2004. Water pulses and biogeochemical cycles in arid and semiarid ecosystems. Oecologia 141, 221235.

Bailey, R.G., 2014. Ecoregions - The Ecosystem Geography of the Oceans and Continents., 2nd ed. Springer. Biondini, M.E., Patton, B.D., Nyren, P.E., 1998. Grazing Intensity and Ecosystem Processes in a Northern Mixed-Grass Prairie, Usa. Ecological Applications 8, 469-479. https://doi.org/10.1890/10510761(1998)008[0469:GIAEPI]2.0.CO;2

Briske, D. D., Joyce, L. A., Polley, H. W., Brown, J. R., Wolter, K., Morgan, J. A., McCarl, B.A., \& Bailey, D. W. (2015). Climate-change adaptation on rangelands: linking regional exposure with diverse adaptive capacity. Frontiers in Ecology and the Environment, 13(5), 249-256. https://doi.org/10.1890/140266

Brown, J.R., Kluck, D., McNutt, C., Hayes, M., 2016. Assessing Drought Vulnerability Using a Socioecological Framework. Rangelands 38, 162-168. https://doi.org/10.1016/j.rala.2016.06.007

Brown-Brandl, T.M., Nienaber, J.A., Eigenberg, R.A., Mader, T.L., Morrow, J.L., Dailey, J.W., 2006. Comparison of heat tolerance of feedlot heifers of different breeds. Livestock Science 105, 19-26.

Canarini, A., Carrillo, Y., Mariotte, P., Ingram, L., Dijkstra, F.A., 2016. Soil microbial community resistance to drought and links to $\mathrm{C}$ stabilization in an Australian grassland. Soil Biology and Biochemistry.

Cook, J., Nosal, D., Bokan, S., Rizza, J., Lockard, E., 2017. Dryland Pasture Condition Assessment and Guidelines for Colorado Small Acreages. https://extension.colostate.edu/docs/sam/grazing-guide.pdf (accessed 8.2.17).

Cook, J.L., Brummer, J.E., Meiman, P.J., Gourd, T., 1997. Colorado Forage Guide.

Dijkstra, F.A., Blumenthal, D., Morgan, J.A., Pendall, E., Carrillo, Y., Follett, R.F., 2010. Contrasting effects of elevated CO2 and warming on nitrogen cycling in a semiarid grassland. New Phytologist 187, 426-437. https://doi.org/10.1111/j.1469-8137.2010.03293.x

Epstein, H.E., Burke, I.C., Mosier, A.R., 1998. Plant Effects on Spatial and Temporal Patterns of Nitrogen Cycling in Shortgrass Steppe. Ecosystems; New York 1, 374-385. https://doi.org/http://dx.doi.org/10.1007/s100219900031

Epstein, H.E., Gill, R.A., Paruelo, J.M., Lauenroth, W.K., Jia, G.J., Burke, I.C., 2002. The relative abundance of three plant functional types in temperate grasslands and shrublands of North and South America: effects of projected climate change. Journal of Biogeography 29, 875-888. https://doi.org/10.1046/j.13652699.2002.00701.x

Ferrell, G.T., 1996. The influence of insect pests and pathogens on Sierra forests. 
Frankson, R., Kunkel, K.E., 2017. NOAA National Centers for Environmental Information. State Climate Summaries 149-CO.

Gill, R.A., Polley, H.W., Johnson, H.B., Anderson, L.J., Maherall, H., Jackson, R.B., 2002. Nonlinear grassland responses to past and future atmospheric CO2. Nature; London 417, $279-82$. https://doi.org/http://dx.doi.org/10.1038/417279a

Hart, C.R., Carpenter, B.B., 2001. Rangeland Drought Management for Texans: Stocking Rate and Grazing Management.

Havstad, K. M., Peters, D. P. C., Skaggs, R., Brown, J., Bestelmeyer, B., Fredrickson, E., Herrick, J., \& Wright, J. (2007). Ecological services to and from rangelands of the United States. Ecological Economics, 64(2), 261-268. https://doi.org/10.1016/j.ecolecon.2007.08.005

Henz, J., Turner, S., Badini, W., Kenny, J., 2004. Historical Perspectives on Colorado Drought. In: Colorado Drought and Water Supply Assessment. Colorado Water Conservation Board.

Hoover, D.L., Rogers, B.M., 2016. Not all droughts are created equal: the impacts of interannual drought pattern and magnitude on grassland carbon cycling. Global Change Biology 22, 1809-1820. https://doi.org/10.1111/gcb.13161

Integrated Drought Management Programme. 2014. www.droughtmanagement.info IPCC, (Intergovernmental Panel on Climate Change), 2013. Summary for Policymakers. In: Climate Change 2013: The Physical Science Basis. Contribution of Working Group I to the Fifth Assessment Report of the Intergovernmental Panel on Climate Change.

Joyce, L.A., Briske, D.D., Brown, J.R., Polley, H.W., McCarl, B.A., Bailey, D.W., 2013. Climate Change and North American Rangelands: Assessment of Mitigation and Adaptation Strategies. Rangeland Ecology \& Management 66, 512-528. https://doi.org/10.2111/REM-D-12-00142.1

Knapp, A.K., Beier, C., Briske, D.D., Classen, A.T., Luo, Y., Reichstein, M., Smith, M.D., Smith, S.D., Bell, J.E., Fay, P.A., others, 2008. Consequences of more extreme precipitation regimes for terrestrial ecosystems. Bioscience 58, 811-821.

LeValley, R.B., 2014. Alternative Feeds for Cattle During Drought.

Mack, R.N., Simberloff, D., Mark Lonsdale, W., Evans, H., Clout, M., Bazzaz, F.A., 2000. Biotic Invasions: Causes, Epidemiology, Global Consequences, and Control. Ecological Applications 10, 689-710. https://doi.org/10.1890/1051-0761(2000)010[0689:BICEGC]2.0.CO;2

Maczko, K., Tanaka, J.A., Breckenridge, R., Hidinger, L., Heintz, H.T., Fox, W.E., Kreuter, U.P., Duke, C.S., Mitchell, J.E., McCollum, D.W., 2011. Rangeland Ecosystem Goods and Services: Values and Evaluation of Opportunities for Ranchers and Land Managers [WWW Document]. http://dx.doi.org/10.2111/1551-501X-33.5.30. URL http://www.bioone.org/doi/abs/10.2111/1551-501X33.5.30 (accessed 3.9.17).

McCarthy, J.J., Canziani, O.F., Leary, N.A., Dokken, D.J., White, K.S. (Eds.), 2001. Climate change 2001: impacts, adaptation, and vulnerability: contribution of Working Group II to the third assessment report of the Intergovernmental Panel on Climate Change. Cambridge University Press, Cambridge, UK; New York.

Milchunas, D.G., Lauenroth, W.K., Burke, I.C., 1998. Livestock Grazing: Animal and Plant Biodiversity of Shortgrass Steppe and the Relationship to Ecosystem Function. Oikos 83, 65. https://doi.org/10.2307/3546547

Milchunas, D.G., Mosier, A.R., Morgan, J.A., LeCain, D.R., King, J.Y., Nelson, J.A., 2005. Elevated CO2 and defoliation effects on a shortgrass steppe: Forage quality versus quantity for ruminants. Agriculture, Ecosystems \& Environment 111, 166-184. https://doi.org/10.1016/j.agee.2005.06.014

Milchunas, D.G., Sala, O.E., Lauenroth, W.K., 1988. A generalized model of the effects of grazing by large herbivores on grassland community structure. The American Naturalist 132.

Morgan, J.A., Mosier, A.R., Milchunas, D.G., LeCain, D.R., Nelson, J.A., Parton, W.J., 2004. CO2 enhances productivity, alters species composition, and reduces digestibility of shortgrass steppe vegetation. Ecological Applications 14, 208-219. 
National Research Council, 2012. Climate Change: Evidence, Impacts, and Choices: Set of 2 Booklets, with DVD. National Academies Press.

O’Brien, K., Eriksen, S., Nygaard, L.P., Schjolden, A., 2007. Why different interpretations of vulnerability matter in climate change discourses. Climate Policy 7, 73-88. https://doi.org/10.1080/14693062.2007.9685639

Pielke, R.A., Doesken, N., Bliss, O., Green, T., Chaffin, C., Salas, J.D., Woodhouse, C.A., Lukas, J.J., Wolter, K., 2005. Drought 2002 in Colorado: An Unprecedented Drought or a Routine Drought? Pure appl. geophys. 162, 1455-1479. https://doi.org/10.1007/s00024-005-2679-6

Polley, H.W., Briske, D.D., Morgan, J.A., Wolter, K., Bailey, D.W., Brown, J.R., 2013. Climate Change and North American Rangelands: Trends, Projections, and Implications. Rangeland Ecology \& Management 66, 493-511. https://doi.org/10.2111/REM-D-12-00068.1

Rondeau, R.J., Pearson, K.T., Kelso, S., 2013. Vegetation Response in a Colorado Grassland-shrub Community to Extreme Drought: 1999-2010. The American Midland Naturalist 170, 14-25. https://doi.org/10.1674/0003-0031-170.1.14

Ryan, W., Doesken, N., 2013. Drought of 2012 in Colorado. Climatology Report 13-01. Dept. of Atmos.Sci., Colorado State University, Fort Collins, CO.

Salley, S.W., Talbot, C.J., Brown, J.R., 2016. The Natural Resources Conservation Service Land Resource Hierarchy and Ecological Sites. Soil Science Society of America Journal 80, 1. https://doi.org/10.2136/sssaj2015.05.0305

Samson, F.B., Knopf, F.L., Ostlie, W.R., 2004. Great Plains ecosystems: past, present, and future. Wildlife Society Bulletin 32, 6-15. https://doi.org/10.2193/0091-7648(2004)32[6:GPEPPA]2.0.CO;2

Schoeneberger, P.J., Wysocki, D.A., 2012. Geomorphic Description System. Version 4.2.

Shi, Z., Thomey, M.L., Mowll, W., Litvak, M., Brunsell, N.A., Collins, S.L., Pockman, W.T., Smith, M.D., Knapp, A.K., Luo, Y., 2014. Differential effects of extreme drought on production and respiration: synthesis and modeling analysis. Biogeosciences 11, 621-633. https://doi.org/10.5194/bg-11-621-2014

Vose, J.M., Clark, J.S., Luce, C.H., Patel-Weynand, T., 2016. Effects of drought on forests and rangelands in the United States. General technical report WO; $93 \mathrm{~b}$.

Woodhouse, C.A., Overpeck, J.T., 1998. 2000 years of drought variability in the central United States. Bulletin of the American Meteorological Society 79, 2693-2714. 
Appendix

Table A1. Drought Severity Classification (droughtmonitor.unl.edu)

\begin{tabular}{|c|c|c|c|c|c|c|c|}
\hline Category & Description & Possible Impacts & $\begin{array}{l}\text { Palmer } \\
\text { Drought } \\
\text { Severity } \\
\text { Index } \\
\text { (PDSI) }\end{array}$ & $\begin{array}{c}\text { CPC Soil } \\
\text { Moisture } \\
\text { Model } \\
\text { (Percentiles) }\end{array}$ & $\begin{array}{l}\text { USGS Weekly } \\
\text { Streamflow } \\
\text { (Percentiles) }\end{array}$ & $\begin{array}{c}\text { Standardized } \\
\text { Precipitation } \\
\text { Index (SPI) }\end{array}$ & $\begin{array}{l}\text { Objective } \\
\text { Drought } \\
\text { Indicator } \\
\text { Blends } \\
\text { Percentiles }\end{array}$ \\
\hline DO & $\begin{array}{c}\text { Abnormally } \\
\text { Dry }\end{array}$ & $\begin{array}{l}\text { Going into drought: } \\
\text { short-term dryness slowing planting, } \\
\text { growth of crops or pastures } \\
\text { Coming out of drought: } \\
\text { some lingering water deficits } \\
\text { pastures or crops not fully recovered }\end{array}$ & $\begin{array}{c}-1.0 \text { to }- \\
1.9\end{array}$ & 21 to 30 & 21 to 30 & -0.5 to -0.7 & 21 to 30 \\
\hline D1 & $\begin{array}{l}\text { Moderate } \\
\text { Drought }\end{array}$ & $\begin{array}{l}\text { Some damage to crops, pastures } \\
\text { Streams, reservoirs, or wells low, some } \\
\text { water shortages developing or imminent } \\
\text { Voluntary water-use restrictions } \\
\text { requested }\end{array}$ & $\begin{array}{c}-2.0 \text { to }- \\
2.9\end{array}$ & 11 to 20 & 11 to 20 & -0.8 to -1.2 & 11 to 20 \\
\hline D2 & $\begin{array}{l}\text { Severe } \\
\text { Drought }\end{array}$ & $\begin{array}{l}\text { Crop or pasture losses likely } \\
\text { Water shortages common } \\
\text { Water restrictions imposed }\end{array}$ & $\begin{array}{c}-3.0 \text { to }- \\
3.9\end{array}$ & 6 to 10 & 6 to 10 & -1.3 to -1.5 & 6 to 10 \\
\hline D3 & $\begin{array}{l}\text { Extreme } \\
\text { Drought }\end{array}$ & $\begin{array}{l}\text { Major crop/pasture losses } \\
\text { Widespread water shortages or } \\
\text { restrictions }\end{array}$ & $\begin{array}{c}-4.0 \text { to }- \\
4.9\end{array}$ & 3 to 5 & 3 to 5 & -1.6 to -1.9 & 3 to 5 \\
\hline D4 & $\begin{array}{c}\text { Exceptional } \\
\text { Drought }\end{array}$ & $\begin{array}{l}\text { Exceptional and widespread } \\
\text { crop/pasture losses } \\
\text { Shortages of water in reservoirs, } \\
\text { streams, and wells creating water } \\
\text { emergencies }\end{array}$ & -5.0 or less & 0 to 2 & 0 to 2 & -2.0 or less & 0 to 2 \\
\hline
\end{tabular}


Table A2. Common drought indices (modified from (Henz et al., 2004; “Integrated Drought Management Programme," 2014)

\begin{tabular}{|c|c|c|c|}
\hline $\begin{array}{l}\text { Common Drought } \\
\text { Indices }\end{array}$ & Description & Strengths & Weaknesses \\
\hline $\begin{array}{l}\text { Palmer Drought } \\
\text { Severity Index (PSDI) }\end{array}$ & $\begin{array}{l}\text { Relates to meteorological drought and attempts to } \\
\text { measure the duration and intensity of long-term } \\
\text { drought inducing circulating patterns. Calculated } \\
\text { using monthly temperature and precipitation }\end{array}$ & $\begin{array}{l}\text { Used around the world. Uses soil } \\
\text { data and total water balance } \\
\text { methods strengthening its ability to } \\
\text { determine drought }\end{array}$ & $\begin{array}{l}\text { Timescale of } \sim 9 \text { months, which leads to a lag in } \\
\text { identifying drought conditions based upon } \\
\text { simplification of the soil moisture component } \\
\text { within the calculations }\end{array}$ \\
\hline
\end{tabular}

Standardized Precipitation A probability index that considers only precipitation. Index (SPI)

Uses historical precipitation records for any location to develop a probability of precipitation that can be computed at any number of timescales, from 1 month to 48 months or longer

Palmer Crop Moisture Index (CMI)

Palmer Hydrological Drought Index (PHDI)

Surface Water Supply Index (SWSI)
Relates to agricultural drought and measures shortterm drought on a weekly scale and is used to quantify drought's impacts on agriculture during the growing season.

Quantifies reservoir levels, groundwater levels. Based on the original PDSI and takes into account longer-term dryness that will affect water storage, streamflow and groundwater.

Compliments the Palmer indices in Colorado, where mountain snowpack is a key element of water supply. Calculated by river basin, based on snowpack, streamflow, precipitation, and reservoir storage.
Uses precipitation data and time and is applicable in all climate regimes does not include temperature component

Can be used to measure the status of dryness or wetness affecting warm season crops and field activities.

\section{Considers the total water system}

Takes into account the work done by Palmer with PDSI but adds additional information including water supply data (snow accumulation, snowmelt and runoff, and reservoir data), and is calculated at the basin level.
Indicates general conditions and not local variations caused by isolated rain

Frequencies will vary by region and time of year and the impact of management decisions and irrigation are not considered. Responds more slowly to changing conditions than the PDSI

As data sources change or additional data are included, the entire index has to undergo a recalculation to account for these changes in the inputs, making it difficult to construct a homogeneous time series. Since calculations may vary between basins, it is difficult to compare basins or homogeneous regions.

$\mathrm{s}=$ short term, typically $<6$ months (ag and grasslands)

I = long term, typically > 6 months (hydrology and ecology) 
Table A3. Breaks and Soft Breaks Ecological Site Group and Soil Matrix.

\begin{tabular}{|c|c|c|c|c|c|}
\hline \multirow{2}{*}{$\begin{array}{l}\text { Ecological Site Group } \\
\text { Ecological Site }\end{array}$} & \multicolumn{3}{|c|}{ Breaks } & \multicolumn{2}{|c|}{ Soft Breaks } \\
\hline & Limestone Breaks & Sandstone Breaks & Gravel Breaks & Shale Breaks & Gypsum Breaks \\
\hline Site ID* & R069XY058CO & R069XY053CO & R069XY064CO & R069XY048CO & R069XY080CO \\
\hline Landform & $\begin{array}{l}\text { mesas, cuestas, scarps, } \\
\text { hillslopes }\end{array}$ & scarps, mesas & $\begin{array}{l}\text { remnant terraces,ridges, breaks, } \\
\text { edges of terraces, scarps, fan } \\
\text { remnants, hillslopes }\end{array}$ & $\begin{array}{l}\text { hillslopes, pediments, } \\
\text { fan remnants }\end{array}$ & $\begin{array}{l}\text { hillslopes, } \\
\text { pediments }\end{array}$ \\
\hline Slope (\%) & $2-45$ & 3-45 & $2-40$ & $15-40$ & $1-30$ \\
\hline Soil Depth $(\mathrm{cm})$ & $23-50$ & $25-50$ & $>152$ & $25-50$ & $23-50$ \\
\hline Surface Texture & loam, channery loam & $\begin{array}{l}\text { sandy loam, channery sandy } \\
\text { loam, channery very fine } \\
\text { sandy loam }\end{array}$ & $\begin{array}{l}\text { gravelly loam, gravelly sandy loam, } \\
\text { gravelly sand, gravelly loamy sand, } \\
\text { very gravelly sandy loam }\end{array}$ & clay, silty clay & loam \\
\hline$A W C(\mathrm{~cm})$ & $10-20$ & $3-5$ & $5-15$ & $8-10$ & $5-10$ \\
\hline $\begin{array}{l}\text { Surface Fragments } \\
(<7.6 \mathrm{~cm})\end{array}$ & $0-35$ & $0-35$ & $5-60$ & $0-14$ & $0-6$ \\
\hline $\begin{array}{l}\text { Subsurface Fragments } \\
(<7.6 \mathrm{~cm})\end{array}$ & $0-35$ & $0-35$ & $0-35$ & $0-14$ & $0-14$ \\
\hline $\begin{array}{l}\text { Electrical conductivity } \\
(\mathrm{mmhos} / \mathrm{cm})\end{array}$ & $0-4$ & $0-2$ & $0-4$ & $0-8$ & $8-16$ \\
\hline Soils & Penrose & Travessilla, Rizozo & Cascajo, Karval, Schamber, Chicosa & Midway & $\begin{array}{l}\text { Ovmesa, Shingle, } \\
\text { Variant }\end{array}$ \\
\hline Acres & 449,787 & 559,071 & 71,967 & 52,773 & 6,193 \\
\hline
\end{tabular}

*Complete ecological site descriptions can be found at https://esis.sc.egov.usda.gov 
Table A4. Sandy, Saline and Loamy Upland Ecological Site Group and Soil Matrix

\begin{tabular}{|c|c|c|c|c|c|c|c|c|c|}
\hline $\begin{array}{l}\text { Ecological } \\
\text { Site Group }\end{array}$ & & Sandy Uplar & & & Saline Upland & & & Loamy Upland & \\
\hline $\begin{array}{l}\text { Ecological } \\
\text { Site }\end{array}$ & Deep Sands & Choppy Sands & Sandy Plains & Salt Flat & $\begin{array}{l}\text { Sandy } \\
\text { Salt Flats }\end{array}$ & Alkaline Plains & Loamy Plains & Clayey Plains & Shaly Plains \\
\hline Site ID* & R069XY019CO & R069XY021CO & R069XY026CO & R069XY033CO & R069XY032CO & R069XY047CO & R069XY006CO & R069XY042CO & R069XY046CO \\
\hline Landform & $\begin{array}{l}\text { stabilized sand } \\
\text { sheets, } \\
\text { hillslopes, } \\
\text { ridges }\end{array}$ & $\begin{array}{l}\text { hillslopes, } \\
\text { ridges, } \\
\text { blowouts }\end{array}$ & $\begin{array}{l}\text { hillslopes, ridges, } \\
\text { interfluves, } \\
\text { stabilized sand } \\
\text { sheets, } \\
\text { drainageways, fan } \\
\text { remnants }\end{array}$ & $\begin{array}{l}\text { flood plains, } \\
\text { stream } \\
\text { terraces, } \\
\text { interfluves, } \\
\text { drainageways, } \\
\text { fans }\end{array}$ & interfluves & $\begin{array}{l}\text { hillslopes, } \\
\text { pediments, } \\
\text { ridges, } \\
\text { interfluves, fan } \\
\text { remnants, } \\
\text { drainageways } \\
\end{array}$ & $\begin{array}{l}\text { interfluves, fan } \\
\text { remnants, } \\
\text { terraces, } \\
\text { ridges, } \\
\text { hillslopes } \\
\end{array}$ & $\begin{array}{l}\text { hillslopes, } \\
\text { interfluves, } \\
\text { fan remnants, } \\
\text { drainageways, } \\
\text { terraces, } \\
\text { pediments }\end{array}$ & $\begin{array}{l}\text { hillslopes, } \\
\text { pediments, } \\
\text { ridges, } \\
\text { interfluves } \\
\end{array}$ \\
\hline Slope (\%) & $1-25$ & $5-25$ & $0-18$ & $0-5$ & $0-2$ & $0-15$ & $0-10$ & $0-15$ & $3-18$ \\
\hline $\begin{array}{l}\text { Soil Depth } \\
(\mathrm{cm})\end{array}$ & $>152$ & $>152$ & $>152$ & $>152$ & $>152$ & $50-152$ & $50-152$ & $50-152$ & $25-102$ \\
\hline $\begin{array}{l}\text { Surface } \\
\text { Texture }\end{array}$ & $\begin{array}{l}\text { loamy sand, } \\
\text { sand }\end{array}$ & sand & $\begin{array}{l}\text { sandy loam, loamy } \\
\text { sand, sandy clay } \\
\text { loam, fine sandy } \\
\text { loam }\end{array}$ & $\begin{array}{l}\text { silty clay loam, } \\
\text { clay loam, clay, } \\
\text { silty clay }\end{array}$ & loamy sand & $\begin{array}{l}\text { clay, clay loam, } \\
\text { silty clay loam }\end{array}$ & $\begin{array}{l}\text { loam, silt } \\
\text { loam, clay } \\
\text { loam, silty } \\
\text { clay loam, fine } \\
\text { sandy loam } \\
\end{array}$ & $\begin{array}{l}\text { clay loam, silty } \\
\text { clay loam, silty } \\
\text { clay }\end{array}$ & $\begin{array}{l}\text { silty clay, silty } \\
\text { clay loam, } \\
\text { clay, clay loam }\end{array}$ \\
\hline$A W C(\mathrm{~cm})$ & $5-13$ & $5-8$ & $5-20$ & $8-20$ & $5-20$ & $13-20$ & $10-23$ & $10-23$ & $10-20$ \\
\hline $\begin{array}{l}\text { Surface Frags. } \\
(<7.6 \mathrm{~cm})\end{array}$ & 0 & 0 & $0-15$ & 0 & 0 & 0 & 0 & $0-8$ & $0-25$ \\
\hline $\begin{array}{l}\text { Subsurface } \\
\text { Frags. } \\
(<7.6 \mathrm{~cm})\end{array}$ & $0-5$ & $0-5$ & 0 & 0 & 0 & $0-15$ & $0-25$ & $0-15$ & $0-35$ \\
\hline $\begin{array}{l}\text { EC } \\
\text { (mmhos/cm) }\end{array}$ & $0-0.2$ & $0-2$ & $0-4$ & $2-16$ & $2-16$ & $2-18$ & $0-8$ & $0-15$ & $2-16$ \\
\hline Soils & Valent, Wigton & Valent & $\begin{array}{l}\text { Olney, Vonid, } \\
\text { Oterodry, Ascalon, } \\
\text { Gilcrest, Haxtun, } \\
\text { Bresser, Truckton, } \\
\text { Kimera, Romound, } \\
\text { Yattle, Oterodry, } \\
\text { Fort, Ulm, Sitcan, } \\
\text { Minnequa }\end{array}$ & $\begin{array}{l} \\
\text { Arvada, } \\
\text { Deertrail, } \\
\text { Limon, Beckton }\end{array}$ & Keyner & $\begin{array}{l}\text { Deertrail, Litle, } \\
\text { Pultney, Ordway, } \\
\text { Tyrone, Cadoma, } \\
\text { Heldt, Razor, } \\
\text { Absted, Keyner, } \\
\text { Manzanola, } \\
\text { Aguilar }\end{array}$ & $\begin{array}{l}\text { Almagre, } \\
\text { Bacid, Fort, } \\
\text { Kim, Kimera, } \\
\text { Manvel, } \\
\text { Minnequa, } \\
\text { Villedry, } \\
\text { Wapiti, Wilid }\end{array}$ & 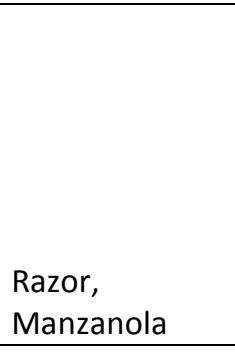 & $\begin{array}{l}\text { Samsil, } \\
\text { Ordway, } \\
\text { Shingle, } \\
\text { Midway, } \\
\text { Razor, } \\
\text { Thedalund, } \\
\text { Gaynor, } \\
\text { Pultney }\end{array}$ \\
\hline Acres & 184,785 & 36,914 & $1,160,362$ & 267,066 & 9,958 & 427,690 & $3,288,200$ & 297,842 & 299,024 \\
\hline
\end{tabular}

*Complete ecological site descriptions can be found at https://esis.sc.egov.usda.gov/ 
Table A5. Lowland and Depressions Ecological Site Group and Soil Matrix.

\begin{tabular}{|c|c|c|c|c|c|}
\hline $\begin{array}{l}\text { Ecological Site } \\
\text { Group }\end{array}$ & & Lowland & & Dep & ssions \\
\hline Ecological Site & Sandy Bottomland & Saline Overflow & Salt Meadow & Plains Swale & $\begin{array}{l}\text { Saline } \\
\text { Plains Swale }\end{array}$ \\
\hline Site ID* & R069XY031CO & R069XY037CO & R069XY030CO & R069XY011CO & R069XY012CO \\
\hline Landform & $\begin{array}{l}\text { flood plains, flood plain } \\
\text { steps, stream terraces }\end{array}$ & $\begin{array}{l}\text { flood plains, stream terraces, } \\
\text { interfluves, drainageways, fan } \\
\text { remnants, flood plain steps }\end{array}$ & $\begin{array}{l}\text { stream terraces, flood plain steps, } \\
\text { flood plains, fans, swales }\end{array}$ & $\begin{array}{l}\text { closed } \\
\text { depression }\end{array}$ & $\begin{array}{l}\text { closed } \\
\text { depression }\end{array}$ \\
\hline Slope (\%) & $0-2$ & $0-3$ & $0-2$ & $0-1$ & $0-1$ \\
\hline Soil Depth $(\mathrm{cm})$ & $>152$ & $>152$ & $>152$ & $>152$ & $>152$ \\
\hline Surface Texture & $\begin{array}{l}\text { sand, loam, sandy loam, } \\
\text { fine sandy loam, loamy } \\
\text { sand }\end{array}$ & $\begin{array}{l}\text { silt loam, loam, clay loam, silty clay } \\
\text { loam, silty clay, clay }\end{array}$ & $\begin{array}{l}\text { loam, clay loam, sandy loam, loamy } \\
\text { sand, silty clay loam, silty clay }\end{array}$ & loam & silty clay \\
\hline $\mathrm{AWC}(\mathrm{cm})$ & $3-16$ & $7-22$ & $2-23$ & 2 & $2-3$ \\
\hline $\begin{array}{l}\text { Surface Fragments } \\
(<7.6 \mathrm{~cm})\end{array}$ & 0 & $0-5$ & 0 & 0 & 0 \\
\hline $\begin{array}{l}\text { Subsurface } \\
\text { Fragments } \\
(<7.6 \mathrm{~cm})\end{array}$ & $0-5$ & $0-15$ & $0-5$ & 0 & 0 \\
\hline $\begin{array}{l}\text { Electrical } \\
\text { conductivity } \\
\text { (mmhos } / \mathrm{cm})\end{array}$ & $0-4$ & $0-16$ & $0-16$ & $0-2$ & $0-8$ \\
\hline Soils & Bankard, Glenberg, Ellicott & $\begin{array}{l}\text { Absted, Limon, Sampson, Rago, Shanta, } \\
\text { Tyrone, Hackamore, Manzanola, } \\
\text { Haversid }\end{array}$ & $\begin{array}{l}\text { Bloom, Apishapa,Cheraw, Bentfort, } \\
\text { Kreybill, Las Animas, Las, Seldom, } \\
\text { Keyner }\end{array}$ & $\begin{array}{l}\text { Ustertic } \\
\text { Hapargids }\end{array}$ & $\begin{array}{l}\text { Chromic } \\
\text { Haplotorrert }\end{array}$ \\
\hline Acres & 107,021 & 284,481 & 115,623 & 1,013 & 820 \\
\hline
\end{tabular}

*Complete ecological site descriptions can be found at https://esis.sc.egov.usda.gov 


\section{Acknowledgments}

This work was supported by the USDA Climate Hubs and Natural Resources Conservation Service - Soil Science Division. We thank Laura Craven (NRCS-MLRA 69 Project Leader and Soil Scientist), Kimberly Diller (NRCS-MLRA 69 Ecological Site Specialist), and Ben Berlinger (NRCS Affiliate Ecological Resources Specialist) for contributing to this document. Thank you to Dustin Ward (New Mexico State University) for his support and assistance with the climate maps. 